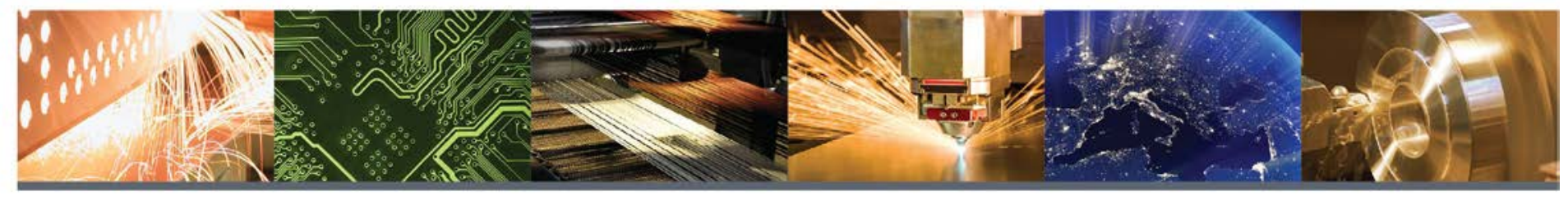

\title{
Clean Energy Manufacturing Analysis Center Benchmark Report: Framework and Methodologies
}

Debra Sandor, Donald Chung, David Keyser, Margaret Mann, and Jill Engel-Cox National Renewable Energy Laboratory

CEMAC is operated by the Joint Institute for Strategic Energy Analysis for the U.S. Department of Energy's Clean Energy Manufacturing Initiative.

Technical Report

NREL/TP-6A50-67666

May 2017

Contract No. DE-AC36-08GO28308 


\section{Clean Energy Manufacturing Analysis Center Benchmark Report: Framework and Methodologies}

Debra Sandor, Donald Chung, David Keyser, Margaret Mann, and Jill Engel-Cox National Renewable Energy Laboratory

Prepared under task number AM05.8000

Clean Energy Manufacturing Analysis Center 15013 Denver West Parkway Golden, CO 80401 303-275-3000 www.manufacturingcleanenergy.org
CEMAC is operated by the Joint Institute for Strategic Energy Analysis for the U.S. Department of Energy's Clean Energy Manufacturing Initiative.

Technical Report

NREL/TP-6A50-67666

May 2017

Contract No. DE-AC36-08GO28308 


\section{NOTICE}

This report was prepared as an account of work sponsored by an agency of the United States government. Neither the United States government nor any agency thereof, nor any of their employees, makes any warranty, express or implied, or assumes any legal liability or responsibility for the accuracy, completeness, or usefulness of any information, apparatus, product, or process disclosed, or represents that its use would not infringe privately owned rights. Reference herein to any specific commercial product, process, or service by trade name, trademark, manufacturer, or otherwise does not necessarily constitute or imply its endorsement, recommendation, or favoring by the United States government or any agency thereof. The views and opinions of authors expressed herein do not necessarily state or reflect those of the United States government or any agency thereof.

Available electronically at SciTech Connect: http:/www.osti.gov/scitech

Available for a processing fee to U.S. Department of Energy and its contractors, in paper, from:

U.S. Department of Energy Office of Scientific and Technical Information P.O. Box 62

Oak Ridge, TN 37831-0062

OSTI http://www.osti.gov

Phone: 865.576 .8401

Fax: 865.576.5728

Email: reports@osti.gov

Available for sale to the public, in paper, from:

U.S. Department of Commerce National Technical Information Service 5301 Shawnee Road Alexandria, VA 22312

NTIS http://www.ntis.gov

Phone: 800.553 .6847 or 703.605 .6000

Fax: 703.605 .6900

Email: orders@ntis.gov 


\section{List of Acronyms}

ASP

CEMAC

$\mathrm{C}-\mathrm{Si}$

FD

GDP

HS

HTS

$\mathrm{I}-\mathrm{O}$

ISIC

ITC

Li-ion

NAICS

NREL

OECD

PV

SAM

STAN

USITC

USD

VA average selling price

Clean Energy Manufacturing Analysis Center

crystalline silicon

final demand

gross domestic product

harmonized schedule

harmonized tariff schedule

input-output

international standard industrial classification

International Trade Centre

lithium-ion

North American industrial classification system

National Renewable Energy Laboratory

Organization for Economic Cooperation and Development photovoltaic

social accounting matrix

OECD Structural Analysis Database

United States International Trade Commission

U.S. dollars

value added 


\section{Table of Contents}

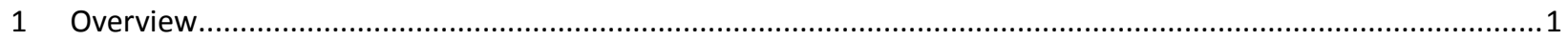

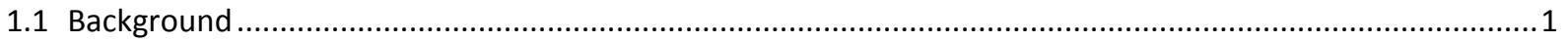

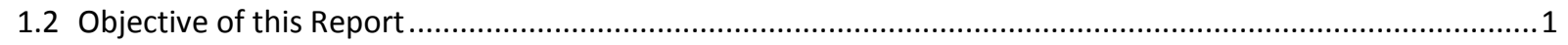

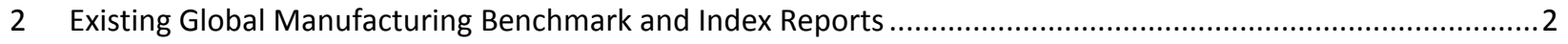

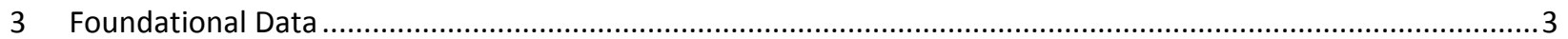

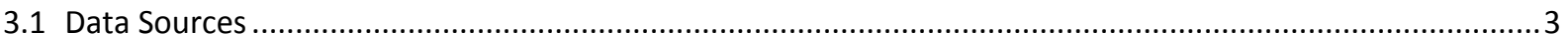

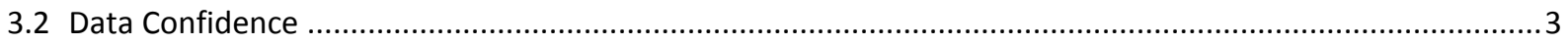

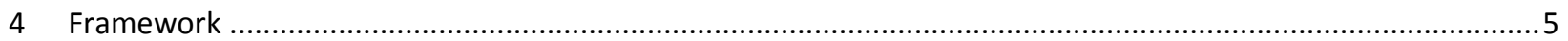

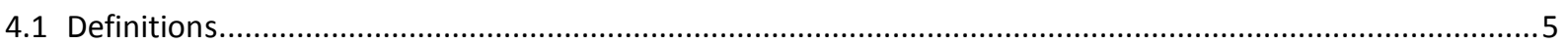

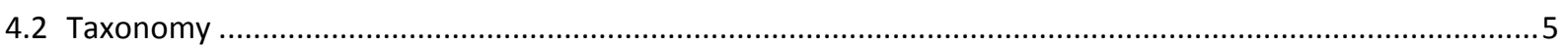

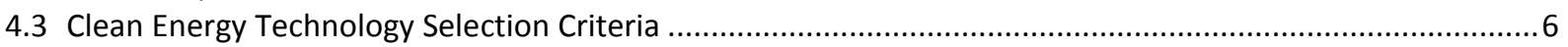

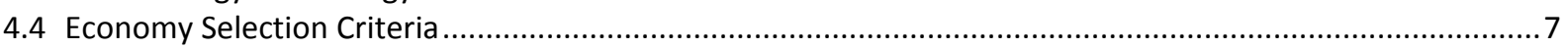

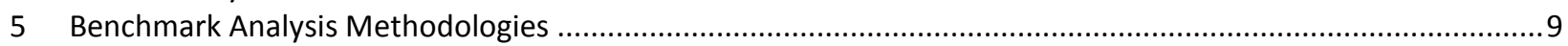

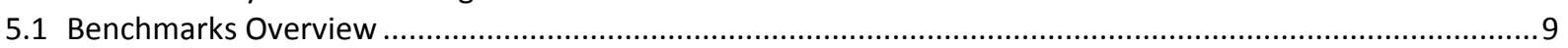

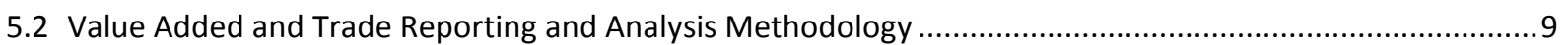

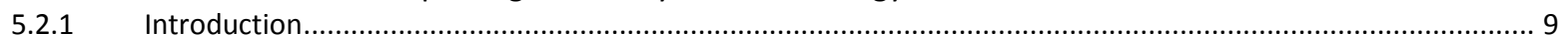

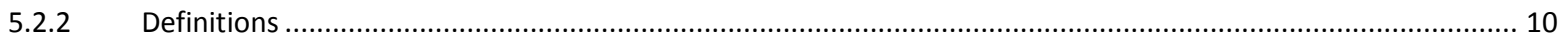

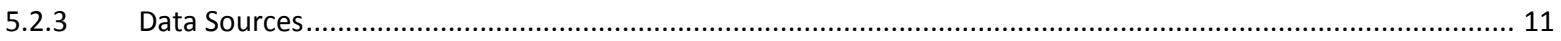

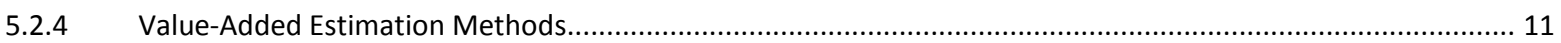

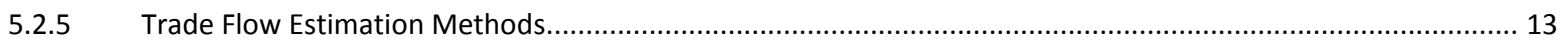

5.3 Market Benchmark Analysis Methodology .................................................................................. 13

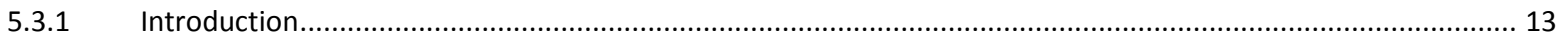

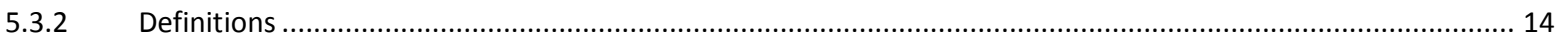

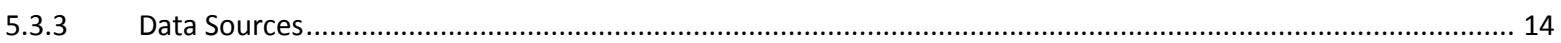

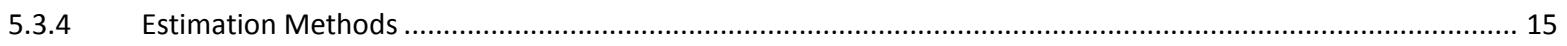

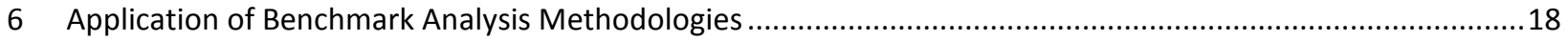

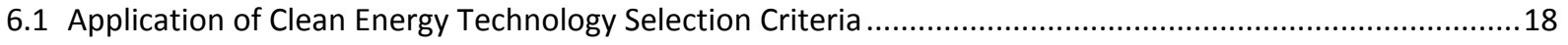

6.2 Application of Supply Chain Element Selection Criteria .............................................................................20

6.3 Application of Value Added and Trade Benchmark Methodologies....................................................26

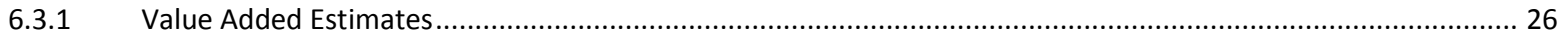

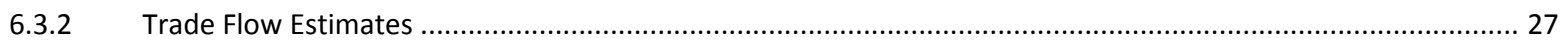

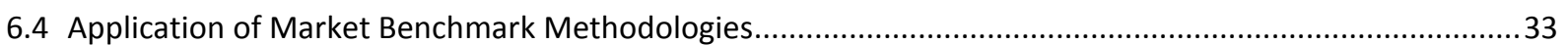

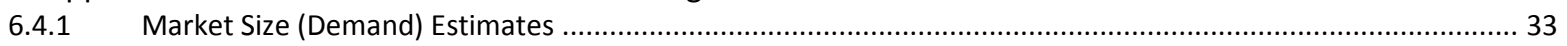

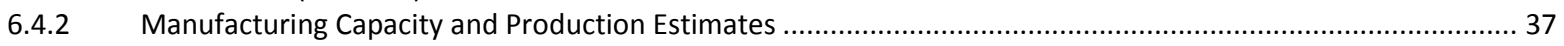

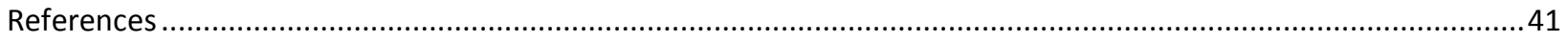

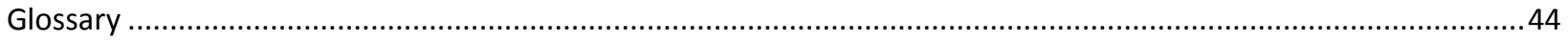




\section{List of Figures}

Figure 1. Clean energy manufacturing supply chain links and examples

\section{List of Tables}

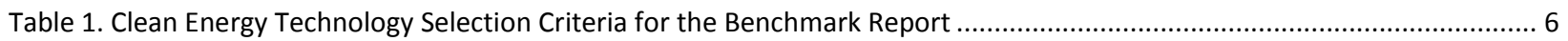

Table 2. Criteria for Including Specific Value Chain Elements in the Benchmark Report........................................................ 7

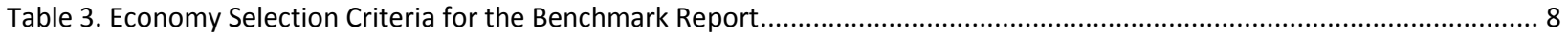

Table 4. FY16 Benchmark Report Technology Selection Criteria Summary ….................................................................... 19

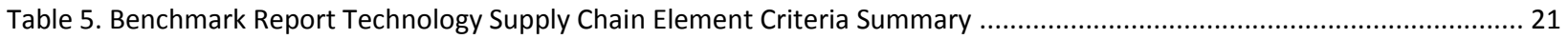

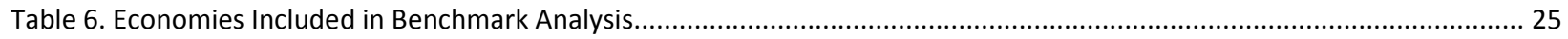

Table 7. OECD I-O Industry Categories Used for Supply Chain Elements Included in Benchmark Report ..................................26

Table 8. Six-Digit Harmonized System Codes for Select Clean Energy Technologies ............................................................. 27

Table 9. Level of Detail in "Photosensitive Semiconductor" Trade Data for PV and LED Products.............................................28

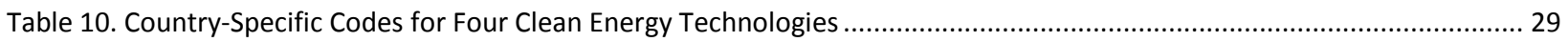

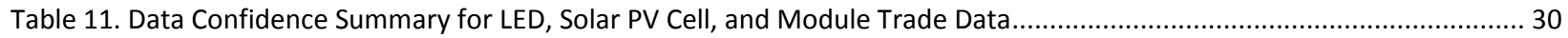

Table 12. Data Confidence Summary for Solar Cell and Module Trade Data......................................................................... 31

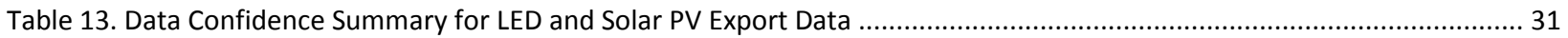

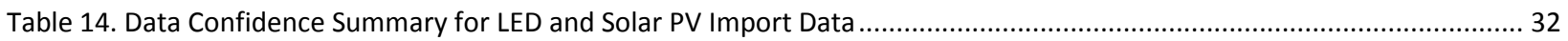

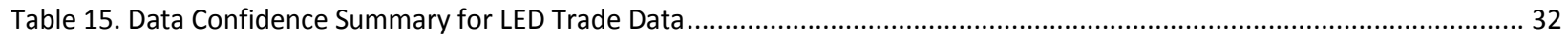

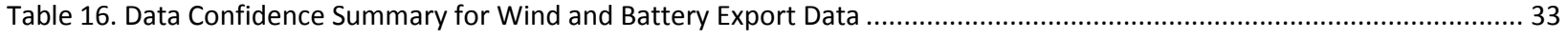

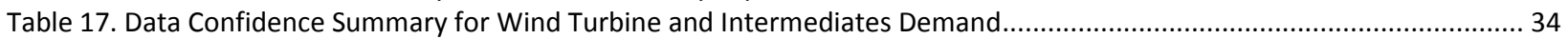

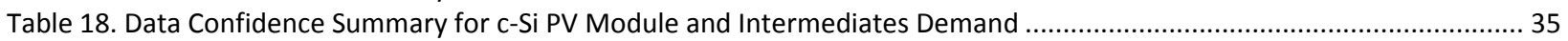

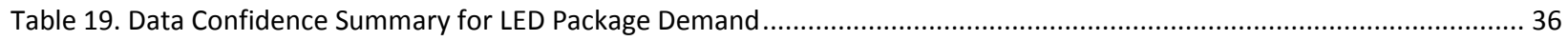

Table 20. Data Confidence Summary for Li-ion Battery Cell Demand ................................................................................... 37

Table 21. Data Confidence Summary for Wind Turbine Component Manufacturing Capacity and Production ............................ 38

Table 22. Data Confidence Summary for c-Si PV Module Manufacturing Capacity and Production ............................................ 39

Table 23. Data Confidence Summary for LED Package Manufacturing Capacity and Production............................................... 39

Table 24. Data Confidence Summary for Li-ion Battery Cell Manufacturing Capacity............................................................ 40 


\section{Overview}

\subsection{Background}

At the request of the U.S. Department of Energy Office of Energy Efficiency and Renewable Energy, the Clean Energy Manufacturing Analysis Center (CEMAC) developed Benchmarks of Global Clean Energy Manufacturing (CEMAC 2017) to provide an annual assessment of the global state of clean energy manufacturing. The report is designed for government officials, policymakers, and industry decision makers to inform energy policy, investment strategies, and other decisions to promote economic growth. The vision is that the report will become the definitive assessment of clean energy manufacturing status globally.

\subsection{Objective of this Report}

This report documents the CEMAC methodologies for developing and reporting annual global clean energy manufacturing benchmarks. The report reviews previously published manufacturing benchmark reports and foundational data, establishes a framework for benchmarking clean energy technologies, describes the CEMAC benchmark analysis methodologies, and describes the application of the methodologies to the manufacturing of four specific clean energy technologies. 


\section{Existing Global Manufacturing Benchmark and Index Reports}

In recent years, a variety of organizations-both public and private-have published benchmark or index reports on the shifting dynamics of global markets, including in the manufacturing sector. As a first step in developing Benchmarks of Global Clean Energy Manufacturing (CEMAC 2017), selected reports were reviewed to identify best practices in manufacturing benchmarking, leverage methodologies and reporting approaches, avoid duplication of effort, and inventory potential data sources. The full list and summary of these reports is available on request.

Overall, these reports provide insight on a range of key issues-including contribution of manufacturing to the global economy, drivers of global competitiveness, impacts of policy frameworks, and overall value-added assessment-both from historical and forward-looking perspectives. In addition, a number of these reports focus on clean energy technologies, illuminating where clean energy markets are expanding and identifying new opportunities for trade.

In general, the published benchmark reports evaluate and compare key parameters-as defined by the individual study and generated through analysis of public and industry data or surveys of leaders in key manufacturing industries-on a normalized and composite basis. These composite benchmark or index values are then used to rank countries or products of interest. So while all of the reports reviewed provide high-level assessments of the global manufacturing and competitiveness landscape for the technologies covered, they do not generate benchmarks at the level of granularity-by manufacturing supply chain link-targeted in Benchmarks of Global Clean Energy Manufacturing (CEMAC 2017).

Nonetheless, the benchmark report review was useful in identifying data sources, potential technology selection criteria, and creative data display options. For example, the Global PV Manufacturing Attractiveness Index 2015 (PVMAX) (Anand 2015) presents an index for 50 countries, based on business environment, access to demand, photovoltaic (PV) manufacturing support, and all-in costs in each country. Some of the criteria laid out in this report were included in the clean energy technology selection criteria for Benchmarks of Global Clean Energy Manufacturing (CEMAC 2017). In addition, although not strictly benchmark reports, the Top Markets reports (ITA 2015) summarize and rank the export opportunities for U.S. manufacturers of renewable and smart-grid technologies by country. These reports were used to inform the decisions which countries to include in Benchmarks of Global Clean Energy Manufacturing (CEMAC 2017).

In summary, published benchmark reports have not examined global clean energy manufacturing at the level of disaggregation required to understand the impacts of each link in the manufacturing value chain across the diverse set of clean energy technologies. The methodologies developed for the CEMAC benchmark analysis were designed to begin filling this gap. 


\section{Foundational Data}

\subsection{Data Sources}

To ensure that the best data sources will be consistently employed in developing benchmarks, a review of potential data sources was completed. Data sources range from free, publicly available data sets compiled by government and trade entities to proprietary, fee-based industry-compiled databases. From this review, the following data sources are candidates to support the benchmark development, depending on the country and technologies.

- Governmental organizations, including:

- Bureau of Economic Analysis-Annual Industry Accounts (BEA 2017)

- Eurostat (for European countries) (Eurostat 2017)

- International Trade Centre (ITC) Trade Map (ITC 2017a)

- ITC Market Analysis Tools Portal (ITC 2017b)

- OECD STructural ANalysis Database (STAN) (OECD 2016)

- U.S. International Trade Commission's (USITC) Interactive Trade and Tariff database (USITC 2017)

- Commercial market research providers, such as:

- Advanced Automotive Batteries (https://www.advancedautobat.com)

- Avicenne Energy (http://www.avicenne.com)

- Bloomberg New Energy Finance (https://about.bnef.com)

- Greentech Media (https://www.greentechmedia.com)

- MAKE Consulting (http://www.consultmake.com)

- Navigant Consulting (https://www.navigant.com)

- Yole Développement (http://www.yole.fr)

- Yano Research (https://www.yanoresearch.com).

\subsection{Data Confidence}

This study provides a unique perspective of the clean energy manufacturing value proposition. The data needed to estimate the benchmarks at the desired level of disaggregation are not available for all technologies included in Benchmarks of Global Clean Energy Manufacturing (CEMAC 2017). By applying technology-specific engineering assumptions and analysis best practices, along with consultation and review by experts from industry and academia, we estimated benchmark metrics across the manufacturing value chain. However, our level of confidence in the data supporting each benchmark varies by technology. To summarize the general assumptions required to estimate each benchmark, we use a color-coding scheme: 
- Green: Data source is published in a respected journal, report, or article or by a respected organization, including NREL or CEMAC

- Yellow: Data are extrapolated from one or more sources in which at least one is green; one or two assumptions are applied for calculations

- Orange: Data are extrapolated from one or more sources in which at least one is green; three or more assumptions are applied in calculations

- Gray: Data are unavailable (applies only to upstream trade data). 


\section{Framework}

The framework establishes the crosscutting features for all the benchmarks, including specific definitions, taxonomy of the value chain links for the development of the benchmarks, and screening criteria for selection of technologies and countries to include in Benchmarks of Global Clean Energy Manufacturing (CEMAC 2017).

\subsection{Definitions}

CEMAC defines clean energy technologies as those that produce energy with fewer environmental impacts than conventional technologies or that enable existing technologies to operate more efficiently, consuming fewer natural resources to deliver energy services. Clean energy technologies may include renewable energy, clean non-renewable energy, and energy efficiency technologies for electricity generation, fuel production, and sustainable transportation. CEMAC conducts analysis on technology end products, components, and enabling materials and techniques; however, the focus of Benchmarks of Global Clean Energy Manufacturing (CEMAC 2017) is on the end products and their innovative components that enable cleaner energy. Other terminology used throughout the report is defined in the Glossary.

\subsection{Taxonomy}

A consistent, high-level process flow outlining the value-added "links" in the manufacturing supply chain was implemented for Benchmarks of Global Clean Energy Manufacturing (CEMAC 2017) reporting. The four links are: raw materials, processed materials, subcomponents, and clean energy technology end products, as shown with examples in Figure 1 and defined in the Glossary. This structure facilitates communication of benchmark results and rollup of clean energy data across technologies and provides flexibility to address the significant manufacturing differences (e.g., raw materials extraction and processing, subcomponents, and processes) for each clean energy technology.

The technologies listed in Figure 1 are included in Benchmarks of Global Clean Energy Manufacturing (CEMAC 2017). 


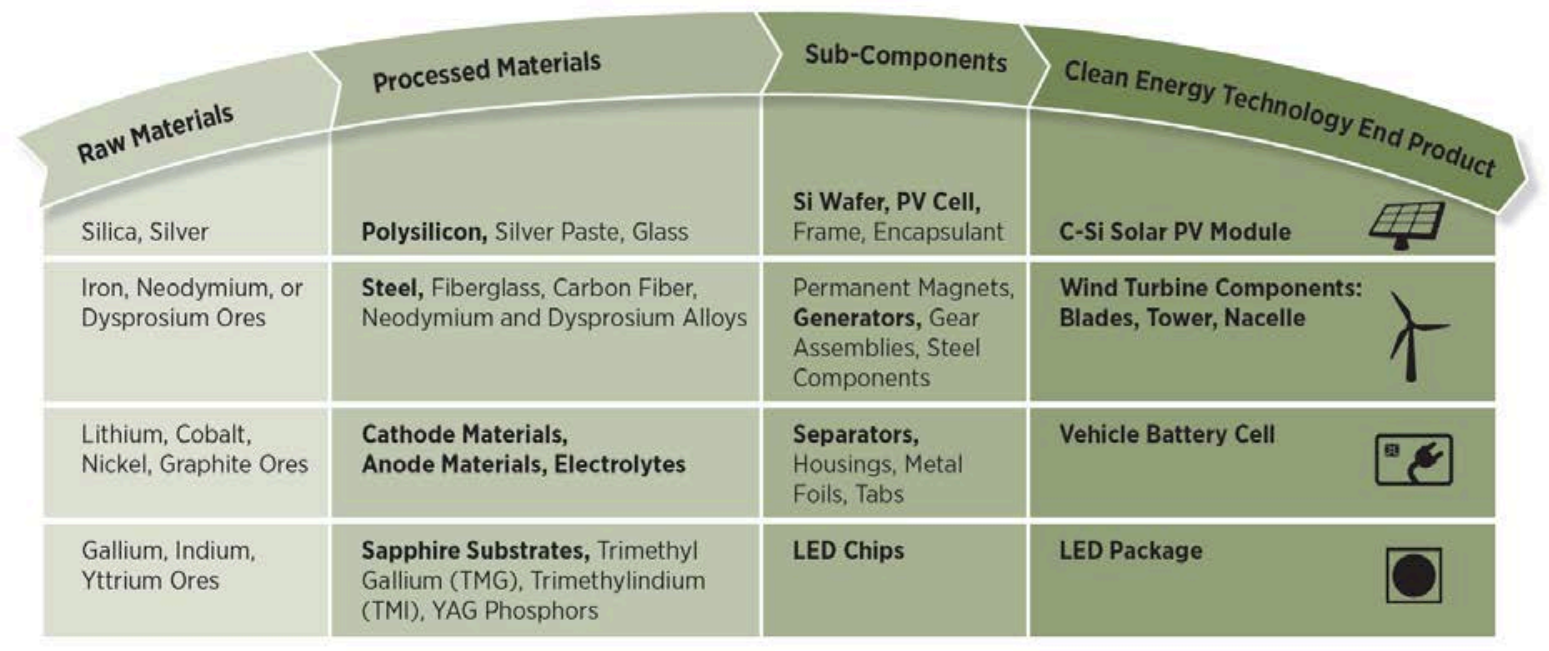

Figure 1. Clean energy manufacturing supply chain links and examples

\subsection{Clean Energy Technology Selection Criteria}

The definition of clean energy technologies is very broad; therefore, the technologies selected to be part of the benchmark need to be both representative of the broader sector and have sufficient information to be quantifiable in a high-quality manner. The criteria for including clean energy technologies in Benchmarks of Global Clean Energy Manufacturing (CEMAC 2017) are defined in Table 1.

Table 1. Clean Energy Technology Selection Criteria for the Benchmark Report

\section{Criteria}

1. End product with understood value chain for key links

2. Completeness of manufacturing value chain data available or NREL/CEMAC manufacturing cost analysis completed

3. Global market size and/or projected growth and room for growth

4. Potential impact on carbon intensity or energy efficiency

5. Opportunities for innovation within manufacturing supply chain

\section{How Criteria are Evaluated}

\section{CEMAC analyst evaluation Product currently available or announced by $>5$ companies \\ CEMAC analyst evaluation \\ At least $50 \%$ data in existing data sets or study already funded or completed}

World Energy Outlook; REN21; secondary analyst reports

Expert evaluation with World Energy Outlook and other reports

Expert evaluation
Investment $>$ U.S. $\$ 5$ billion/year or growing $>20 \%$ per year

Deployment market estimated to be $>100 \mathrm{GW}$ in 2020 (WEO medium-term scenario)

Consensus among three experts

Criteria 1 and 2 were evaluated in consultation with CEMAC analysts and with technology experts within NREL and partner laboratories. Criteria 3 was evaluated using annual global market reports, such as the World Energy Outlook (IEA 2015) and REN21 Global Status Report (REN21 2015). Criteria 4 and 5 were evaluated through a survey process with experts from 
NREL, partner national laboratories, the advisory committee, and others. A description of how the technologies for Benchmarks of Global Clean Energy Manufacturing (CEMAC 2017)were evaluated against each of the criteria is included in Section 6.1.

Once a clean energy technology has been identified, the specific raw materials, processed materials, and subcomponents to be included in the value chain analysis can be defined based on the criteria in Table 2.

Table 2. Criteria for Including Specific Value Chain Elements in the Benchmark Report

\section{Criteria}

1. Raw materials

- Constrained resource

- Unique or enabling process or product

- Imported and exported globally

- Impact on overall cost

- Critical to quality

2. Processed materials

- Unique or enabling process or product

- Imported and exported globally

- Impact on overall cost

- Critical to quality

3. Subcomponents

- Unique or enabling process or product

- Imported and exported globally

- Impact on overall cost

- Critical to quality
How Criteria are Evaluated

\section{CEMAC analyst}

evaluation/expert review

\section{CEMAC analyst}

evaluation/expert review

Consensus among three internal or external experts

\section{Consensus among three} internal or external experts

\section{Threshold for Inclusion}

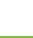


Table 3. Economy Selection Criteria for the Benchmark Report

Criteria

1. Current economy market size and projected growth relative to other countries (technology-specific)

2. Current economy manufacturing capacity relative to other countries (technology-specific)
How Criteria are Evaluated

\section{World Energy Outlook;} REN21; secondary analyst reports

CEMAC analyst evaluation; DOC Top Markets Reports
Threshold for Inclusion

Number of economies required

to cover $>60 \%$ of market

Number of economies required to cover $>60 \%$ of global manufacturing capacity

3. Economy included in value added I- OCED STAN I-O database Yes O database

4. Economy included in import-export database

U.S. International Trade Yes Commission import-export database (HTS-10): World Trade Atlas (HTS-06)

Criteria 1 and 2 in Table 3 focus on identifying the top economies for each technology, based on market size for sales of the end product and manufacturing capacity, with the goal of capturing the majority of the market and manufacturing capacity around the world. Criteria 3 and 4 focus on access to reliable data (e.g., economy coverage in available input-output [I-O] databases and analyst reports) and clean energy manufacturing activities. The top economies for all technologies are included in the report. Benchmarks of Global Clean Energy Manufacturing (CEMAC 2017) included 12 economies. The proposed maximum number of economies to be covered by any future benchmark report is 30 . 


\section{Benchmark Analysis Methodologies}

This section outlines the four benchmarks and then describes the methodologies for measuring each of them in detail. The base year for the first benchmark analysis is 2014, the most recent year for which reliable, comprehensive data were available.

\subsection{Benchmarks Overview}

The metrics developed for Benchmarks of Global Clean Energy Manufacturing (CEMAC 2017) are intended to provide unique insights into the global dynamics and economic impacts of each link in the manufacturing value chain and include:

- Economic benchmarks

- Global clean energy manufacturing value added (VA): For each technology covered, manufacturing VA is estimated for each link of the manufacturing value chain for each economy. This information is reported and aggregated by nation within each technology area and across all technology areas. This metric is intended to be a barometer of how the United States and other economies are doing in terms of manufacturing VA in each relevant technology and in aggregate across all covered clean energy technologies.

- Global clean energy manufacturing trade flows: For each technology covered, for each link of the manufacturing value chain and in aggregate, the total international trade flows and net imports and exports by and between economies is estimated.

- Market benchmarks

- Global clean energy manufacturing capacity and production: For each technology covered, the capacity and production in each link of the manufacturing value chain for each economy is estimated.

- Global clean energy market size: For each technology covered, the total end-use global market size for manufactured clean energy technologies (demand) for each economy is estimated and aggregated across technology areas.

\subsection{Value Added and Trade Reporting and Analysis Methodology}

\subsubsection{Introduction}

The economic health of an economy is typically presented as gross domestic product (GDP), which is a measure of the value of production. Measuring and tracking the value of production of clean energy manufacturing commodities provides important information about how significant these commodities are within an economy, both in terms of production of the commodity itself and how integrated this production is with other producers. This integration could be purchases of goods or services such as raw material inputs or business-to-business services.

Because we live in a world with global, interconnected economies, production of commodities in other economies also has relevance. PV module manufacturers in China, for example, may purchase polysilicon from the United States. These polysilicon sales have value and contribute 
to GDP in the United States. Estimating the value of different steps of production can show where value accrues and how significant each step is to the host economy.

Balance of trade-exports and imports-is also an important component of GDP. Tracking trade between countries provides insight into global flows of clean energy manufacturing products. These illustrate the interconnectedness of different economies globally, whether economies are producers or consumers.

\subsubsection{Definitions}

This section contains definitions of select terms that are used to describe economic and trade benchmark methodologies. VA terms are included to clearly define how they are used for calculations made in this report (see Section 5.2.4) because there is variability in the use of these terms by various experts in differing fields.

- Direct value added is VA from the output of the sector in question. For example, if solar module manufacturing pulled in $\$ 100$ million in revenue in a specific country and $70 \%$ of that went to intermediate inputs, then direct VA would be the remaining $30 \%$.

- Final demand (F) is demand for what is produced by an industry that is not an input for some other product. This demand can come from households, investors, governments, and the rest of the world through net exports. A social accounting matrix (SAM) is a matrix that contains economy-wide data for VA, F, intermediate inputs, and gross output.

- Gross output is a sum of VA and all payments for intermediate inputs. This is a measure of overall economic activity. Gross output is final demand (F) plus intermediate demand or intermediate demand plus VA.

- Indirect value added is VA that is supported by the domestic intermediate expenditures made by the sector in question. This is a comprehensive figure that captures all supplychain activities necessary to support the output of the sector in question (solar module manufacturing in the previous example) within the country in question. Indirect VA from solar module manufacturing in China, for example, would not include polysilicon that is imported from the United States-this is estimated separately. It would include inputs sourced in China.

- Intermediate inputs are payments from a business or industry to other businesses and industries for goods or services used in production.

- Technical coefficients are intermediate inputs as a portion of output for each industry. When all technical coefficients are combined in a matrix, this is referred to as the direct requirements matrix.

- Value added (VA) consists of labor payments, gross operating surplus, and taxes on production and can be a measure of GDP. Labor payments are all payments to workers, including benefits. Gross operating surplus is a property-type income that includes payments for capital (including depreciation) and payments to investors. Profits are included in gross operating surplus. Taxes on production are net payments to or from the 
government. If subsidies paid to an industry from the government are greater than taxes paid by that industry to the government, then taxes will be negative.

\subsubsection{Data Sources}

There are many sources of economic data to track manufacturing VA (the value of production) and trade flows as described here.

\subsubsection{Data Sources for Value-Added Benchmarks}

VA estimates-discussed further in Section 5.2.4-are based on a combination of CEMAC cost analysis, market data (presented in Section 5.3.4), and social accounting data from the Organization for Economic Cooperation and Development (OECD) Structural Analysis (STAN) database (OECD 2016). ${ }^{2}$ While other sources of input-output (I-O) data exist, OECD SAMs are used for all countries to provide consistency.

CEMAC manufacturing cost analysis provides estimates of the critical costs incurred in the manufacture of a given clean technology, attributed to a specific country of origin, for input to the I-O models used to estimate VA. CEMAC technology-specific market analysis provides estimates for the demand for clean-energy-manufactured commodities within countries, which is used in the VA analysis.

\subsubsection{Data Sources for Trade Benchmarks}

Trade flow data come from a number of sources. The USITC provides detailed import and export data to and from the United States. Global trade flows come from the ITC. ${ }^{3}$ Section 5.2.5 contains information about how these data are applied and interpreted.

\subsubsection{Value-Added Estimation Methods}

The use of I-O models to estimate VA for manufacturing commodities without having a comprehensive set of data about their in-country supply chain is a well-established methodology (Miller and Blair 2009). I-O models characterize the economy in terms of purchases (inputs) and sales (outputs), where every input purchased by an industry is an output produced by another. These interactions are represented in a SAM, as outlined in Text Box A. Because these models account for all sales and purchases, they provide a comprehensive view of economic activity required to support a modeled scenario. In addition, because the underlying SAM distinguishes VA and output, if a level of output is known, VA is also known. For example, if VA is $20 \%$ of output then $\$ 100$ of output supports $\$ 20$ of VA.

\footnotetext{
${ }^{2}$ Further information about the OECD STAN database, including the data used in Benchmarks of Global Clean Energy Manufacturing (CEMAC 2017), can be found at http://www.oecd.org/sti/ind/stanstructuralanalysisdatabase.htm.

${ }^{3}$ See www.trademap.org.
} 


\section{Text Box A: I-O Math}

To illustrate simple I-O math using traditional notation, let output be $n \cdot 1$ vector $x$, intermediate inputs $n \cdot n$ matrix $Z$, and final demand $\mathrm{n} \cdot 1$ vector $F$. Variables with $\mathrm{a}^{\wedge}$ represent a normalized $\mathrm{n} \cdot \mathrm{n}$ matrix.

Technical coefficients can be estimated using:

$$
A=Z(\hat{x})^{-1}
$$

Output is defined as both intermediate inputs $(A x)$ and final demand $(F)$ :

$$
x=A x+F
$$

This can be rearranged:

$$
\mathrm{X}=(\mathrm{I}-\mathrm{A})^{-1} \mathrm{~F}
$$

VA is proportional and linear to $x$, so VA and VA coefficients $(V C)$ can be represented as:

$$
V C=V A(\hat{x})^{-1} \text { and conversely } V A=V C \hat{x}
$$

For this benchmark, VA is calculated using market data described in Section 5.3.4, which provides dollar values of production, the direct VA, for clean-energy-manufactured commodities within select countries. In Text Box A, this represents $F$. The resulting output, $x$, includes both direct and indirect output, and can be calculated from this indirect VA.

VA estimates require that expenditures for each component be matched to a corresponding industry. The OECD I-O tables (OECD 2015) contain 34 industries classified by international standard industrial classification (ISIC) rev. 4 codes. ${ }^{4}$ These industries are aggregations of many subsectors. Production revenue, then, is applied to the industry that contains the component. Solar PV cells, for example, are within the computer, electronic, and optical equipment manufacturing sector because this industry contains semiconductor and photosensitive diode manufacturing. LED packages and Li-ion battery cells are also subsectors within this industry.

To minimize double counting, total VA estimates zero out subcomponents of the sector in question in the technical coefficients within SAM. ${ }^{5}$ For example, to estimate the solar PV total VA, expenditures applied to the computer and electronic equipment industry would not include inputs from the computer and electronic equipment industry or mining and quarrying, which includes polysilicon.

VA estimates for each subcomponent include the entire supply chain for that component. These are estimated using unadjusted, standard total requirements tables for each country. VA for solar modules, for example, includes VA from solar cells, wafers, and polysilicon. VA for solar cells would include wafers and polysilicon as well. VA for solar PV as a whole, however, is

\footnotetext{
${ }^{4}$ For more detail on ISIC codes, see http://unstats.un.org/unsd/cr/registry/regcst.asp? $\mathrm{Cl}=27$.

${ }^{5}$ This is the $A$ matrix in Text Box A.
} 
controlled to avoid double counting. ${ }^{6}$ The estimate for solar as a whole includes modules, cells, wafers, and polysilicon-each counted only once. If VA individual subcomponents are added up, the sum will be greater than VA for the technology as a whole.

Production of solar cells, for example, is included in the indirect impact for solar modules. If VA from individual components was aggregated then VA from this aggregation would double-count subcomponents. In the previous example, direct VA from cells is included in indirect VA from modules.

Although I-O analysis is an accepted tool for VA analysis, the method has limitations. I-O models are set up by industry or commodity based on industry aggregation schemes. These are typically the ISIC of all economic activities except for Canada, the United States, and Mexico, which use the North American industrial classification system (NAICS). Demand for a commodity must be applied to the industry that produces that commodity, which typically includes more than the commodity being analyzed. For example, PV module manufacturing would fall under all polysilicon chip manufacturing, which includes computer chips. Thus, indirect VA is not an estimate of VA exclusively applied to PV modules. It is a generalization of VA supported by this type of manufacturing at levels of demand for PV modules. We try to minimize distortions caused by this by only reporting total VA, as opposed to VA by each industry in an economy. In addition, I-O data may not be updated annually, and even when SAMs are updated on an annual basis, they typically lag market data by a year or more.

\subsubsection{Trade Flow Estimation Methods}

Commodities that are traded internationally are categorized by harmonized schedule (HS) codes. HS codes range from 6 to 10 digits, with each additional digit applying greater detail. The international six-digit HS codes are the global standard. Codes greater than six digits that further differentiate products are country-specific. Countries may apply these to imports, exports, or both-there is no international standard for this level of detail. While some clean energy commodities and supply-chain components have specific HS codes, many do not.

Trade flow data on imports is more reliable than data on exports because imports can be taxed. Countries therefore have greater incentive to accurately track and report these data. International trade data are typically released with a minimal reporting lag-usually within three months of the transaction.

\subsection{Market Benchmark Analysis Methodology}

\subsubsection{Introduction}

Market benchmarks are used to inform the VA analysis, as well as serve as indicators for the progress and development of global clean energy demand and manufacturing. Market benchmarks include global market demand size, manufacturing capacity, and manufacturing production for the covered technologies presented on a per-country basis. These data are

\footnotetext{
${ }^{6}$ For more information about this, see Section 6.4.1.
} 
included as benchmarks because they are fundamental measures used in assessing the supply, demand, growth, and trade dynamics occurring within an industry.

\subsubsection{Definitions}

This section contains definitions of select terms that are used to describe market benchmark methodologies.

- Market size is an estimate of the demand for a specific product or service and is typically expressed in units of product volume (e.g., megawatts of PV modules) and in terms of monetary value (e.g., U.S. dollars [USD]). The latter expression of market size accounts for both demand volumes and selling prices. Market size serves as a core metric of demand development and growth over time and is also a key measure of the relative significance of an industry within countries and across the globe. Market size as measured by value is proposed as a key market benchmark.

- Manufacturing capacity refers to the amount of product that could be produced in a given time period by physical plant and other necessary infrastructure (e.g., megawatts of PV modules per year). Production is the actual amount of a product produced, also normalized to a given time period. Annual manufacturing capacity and production are proposed as additional market benchmarks.

Market size, manufacturing capacity, and actual production are presented at both the national and global levels.

\subsubsection{Data Sources}

For established industries, market benchmark data are typically available from a variety of potential sources such as the following:

- Standard market research reports and databases (e.g., Bloomberg New Energy Finance, Navigant, GTM Research, IHS, and Cleantech Group)

- Public financial statements (e.g., quarterly and annual corporate reports)

- Consultant and equity analyst reports (e.g., Lazard, UBS, and Roland Berger)

- Government data (e.g., U.S. Energy Information Administration and International Energy Agency)

- Trade association data (e.g., Solar Energy Industry Association and American Wind Energy Association)

- Customized reports generated via engagements with market research firms and consultants.

To ensure data quality, multiple sources are consulted and compared whenever possible, with good data accuracy indicated via reasonable consensus amongst sources. Where significant variances emerge across data sources, a more detailed examination of each source's methodology and key assumptions will be undertaken to understand the drivers of the 
differences in estimates. Dissimilarities impacting any benchmark values will be documented, along with the reasoning behind selected values and estimation approaches.

\subsubsection{Estimation Methods}

Market size, manufacturing capacity, and production data are all collected from multiple existing secondary sources whenever possible. For more established technologies, such market data are typically reported for the countries and regions comprising the largest contributions to the global market or manufacturing capacity. For industries where market data on critical processed materials or subcomponents are available, benchmarks are collected for each intermediate product as well as for the end product.

Collecting market data from multiple secondary sources allow access to high-value information for relatively low cost. Primary market data collection is a specialized, time-consuming practice that is best left to firms and organizations with the needed infrastructure and expertise. Data from these types of reports may be aggregated, presented as a range, or otherwise synthesized depending upon the industry-specific context and drivers. In all cases, for each technology included in Benchmarks of Global Clean Energy Manufacturing (CEMAC 2017), the exact nature and rationale of data synthesis are documented.

A key risk with this approach is the potential lack of market data-standard reports may not be available for less-developed technologies where markets may still be small or immature. However, such data may be obtained through customized reports and engagements with market research firms and consultants.

\subsubsection{Market Size Estimation}

Market size is commonly reported in units of both volume and value. For market value estimation, both volume and unit price estimates are required, and values are simply the product of volume and unit price. While presenting market size in terms of value allows for market size comparison across countries, technologies, and value chain links, it may obscure underlying market development trends that are of interest. For these reasons, volume- and value-based market size data are both collected whenever available, even though the proposed benchmark will be expressed in terms of value.

The units used to report demand volumes vary across industries. For many clean energy generation technologies, the end-product volume demanded is tracked in units of the nominal power or energy ratings of the products sold. For example, PV-module and wind-turbine demand are reported in units of rated power ( $W_{d c}$ for PV modules, $W_{a c}$ for wind turbines). Lithium-ion (Li-ion) battery and other energy-storage-device demand are reported in units of rated energy capacity (Wh) and LED packages are reported in units of number of packages produced. Prices in each industry are often normalized by the prevailing unit of measure (e.g., PV module prices are reported in dollars per $\mathrm{W}_{\mathrm{dc}}$, wind turbines in dollars per $\mathrm{MW}_{\mathrm{ac}}$, and batteries in dollars per $\mathrm{kWh}$ ).

Units of volume, and subsequent unit prices, can further vary across intermediate products within a single industry. For example, within the PV industry, units of volume reported can vary 
for different intermediate products (e.g., polysilicon volumes and prices are commonly reported by weight in metric tons, or dollars per kilogram, as opposed to the end-product unit of power, or watts). For the purposes of this report, it is desirable to convert all volumes within the supply chain into units consistent with end-product demand. Such conversions require engineering assumptions based upon the detailed technical analyses for each clean energy technology, and these assumptions must be documented and stated explicitly. The need for such conversions, and the actual assumptions used, depend entirely upon the technology being analyzed.

While end-product volume metrics are the simplest and most direct way to track market demand size and growth within an industry, it can be difficult to compare market development across industries because of the incompatibilities in volume units used. Even where the units are similar - such as $W_{d c}$ for PV module power versus $W_{a c}$ for wind turbine powerassumptions and conversions are nonetheless needed to account for the dc-to-ac conversion efficiency of PV systems. Further, these units of volume are not comparable to energy storage demand units of Wh (or any non-power unit of measure).

The most common way to normalize market demand metrics across industries is to use units of value (e.g., USD) to measure size. When not reported distinctly, market size expressed by value is straightforward to compute and is underpinned by two separate estimates: the volume of product demanded and the global average selling price (ASP) for the product. Both of these metrics are typically available from standard market research reports. One caveat with this approach is that ASPs can change quickly and dramatically, especially within high-growth clean energy industries. This variation in price can then mask the volumetric demand development for any given industry over time and possibly distort comparisons across industries. For this reason, CEMAC analyses compute market values from estimates of underlying volumetric demand and ASPs to ensure such dynamics are made explicit.

Volumetric market demand for key intermediate products within an industry are ideally based upon both actual production data for each subsequent downstream intermediate product and the actual change in inventory of the intermediate product. This level of data granularity may prove difficult to find from standard secondary sources, especially for smaller industries. In these cases, the demand for intermediate products can be approximated by assuming that all elements of the value chain are in balance and that no changes in inventory occur within the value chain and, thus, the production volume of the end product is equivalent to the demand for each upstream intermediate product in units normalized to end-product volume units. This assumption (and other simplifying assumptions) may or may not mask important dynamics within the value chain, so analysts apply their best judgment in determining when implementation of such simplifying assumptions is warranted.

\subsubsection{Manufacturing Capacity and Production Estimation}

Manufacturing capacity and production are typically reported in units of product volume per time interval. As with market size estimates, end-product volumetric units may not be the same across materials, subcomponents, or intermediate product volumetric units, so engineering 
estimates may be required to convert all elements of the supply chain into a single volumetric unit.

For benchmarking purposes, we present country-specific capacity and production both in terms of the monetary value of the volume per time, as well as percentage shares of global totals. Presenting the percentage shares of global markets allows easy comparison across countries within a given industry and also provides insight into the relative position of a country across technologies. 


\section{Application of Benchmark Analysis Methodologies}

This section describes the application of the benchmark criteria and methodologies for the Benchmarks of Global Clean Energy Manufacturing (2017) report. The base year for the first benchmark analysis is 2014.

\subsection{Application of Clean Energy Technology Selection Criteria}

The inclusion of the following technologies in Benchmarks of Global Clean Energy Manufacturing (CEMAC 2017.) was based on each industry's strong fit with the CEMAC benchmark inclusion criteria, as summarized in Table 4.

- Crystalline silicon solar PV modules. While the PV industry is well established and maturing, PV still constitutes only about $1 \%$ of global electrical energy production (BNEF New Energy Outlook 2015 Solar). The DOE (2012) SunShot Vision Study estimates that solar energy could meet $14 \%$ of U.S. electricity needs by 2030 and $27 \%$ by 2050, suggesting there still remains strong opportunities for growth and innovation in the sector.

- Wind turbine components. Wind energy has the most installed capacity of any non-hydro renewable energy source. The global wind industry installed more than $51 \mathrm{GW}$ of capacity in 2014, bringing the global total to $370 \mathrm{GW}$, of which the United States has the second-largest installed wind capacity with $66 \mathrm{GW}$ (REN21 2015). Although the wind industry is well established and growing, wind still constitutes only $3 \%$ of global electricity. The DOE (2015a) Wind Vision estimates the U.S. wind generation potential by 2030 as $20 \%$, suggesting there still remains strong opportunities for growth and innovation in the sector.

- Automotive Lithium-ion battery cells. Li-ion battery manufacturing for the automotive industry is in the early stages of commercial production, with electrified vehicles (including pure electric, plug-in hybrid, and hybrid drive vehicle) constituting only $1.6 \%$ of global lightduty vehicle markets in 2015 (Navigant Consulting 2015). The industry is pursuing innovations in both core cell chemistries and manufacturing processes to achieve cost reductions and performance improvements, which are key to electrified vehicle market growth and overall vehicle market penetration.

- LED packages. While LED packages (for a variety of consumer applications) have matured significantly in recent years, costs remain high and market penetration remains low. LED lighting is poised for growth. The DOE (2014) report Energy Savings Forecast of Solid-State Lighting in General Illumination Applications projects that LED lighting could achieve a market share of $84 \%$ of lumen-hour sales in the general illumination market by 2030 , with innovations focused on reducing costs and improving efficacy of LED package components and housing design. 
Table 4. FY16 Benchmark Report Technology Selection Criteria Summary

\section{Clean Energy}

Technologies

\begin{tabular}{|c|c|c|c|c|c|}
\hline & $\begin{array}{l}\text { End product } \\
\text { with } \\
\text { understood } \\
\text { value chain } \\
\text { for key links }\end{array}$ & $\begin{array}{l}\text { Completeness of } \\
\text { manufacturing } \\
\text { value chain data } \\
\text { available or CEMAC } \\
\text { manufacturing cost } \\
\text { analysis completed }\end{array}$ & $\begin{array}{l}\text { Global market size and/or } \\
\text { projected growth }\end{array}$ & $\begin{array}{l}\text { Potential impact on } \\
\text { carbon intensity or } \\
\text { energy efficiency }\end{array}$ & $\begin{array}{l}\text { Opportunities for innovation } \\
\text { within manufacturing supply } \\
\text { chain }\end{array}$ \\
\hline $\begin{array}{l}\text { Crystalline } \\
\text { Silicon Solar } \\
\text { PV Modules }\end{array}$ & $\begin{array}{l}\text { Well-established } \\
\text { global } \\
\text { manufacturing } \\
\text { network }\end{array}$ & $\begin{array}{l}\text { HS codes available; } \\
\text { multiple } \\
\text { NREL/CEMAC } \\
\text { studies completed }\end{array}$ & $\begin{array}{l}\text { U.S. } \$ 150 \text { billion invested in } \\
2014 \text {-increase of 25\% from } \\
2013 \text { (REN21 2015); forecast } \\
\text { growth (2015-2020) of } 12 \% \\
\text { (BNEF 2015, James } 2015 \text {, } \\
\text { Labastida and Gauntlett } 2015 \text { ) }\end{array}$ & $\begin{array}{l}\text { Global solar PV capacity } \\
\text { (2014): } 177 \text { GW (REN21 } \\
\text { 2015); global annual } \\
\text { demand } 43 \text { GW (BNEF } \\
\text { 2015, James } 2015, \\
\text { Labastida and Gauntlett } \\
\text { 2015) }\end{array}$ & $\begin{array}{l}\text { Medium (advanced cell } \\
\text { architectures, polysilicon } \\
\text { purity, and wafer processing } \\
\text { innovation) }\end{array}$ \\
\hline $\begin{array}{l}\text { Wind Turbine } \\
\text { Components }\end{array}$ & $\begin{array}{l}\text { Well-established } \\
\text { global } \\
\text { manufacturing } \\
\text { network }\end{array}$ & $\begin{array}{l}\text { HS codes available; } \\
\text { multiple } \\
\text { NREL/CEMAC } \\
\text { studies completed }\end{array}$ & $\begin{array}{l}\text { U.S. } \$ 99.5 \text { billion in } 2014 \\
\text { (REN21 2015) Focusing on } \\
\text { new capacity additions alone } \\
\text { suggests a potential value of } \\
60-90 \text { billion USD, depending } \\
\text { on global installations (35-50 } \\
\text { GW/year) and expected costs } \\
(1,600-1,800 \text { USD/kW). }\end{array}$ & $\begin{array}{l}\text { Global wind power } \\
\text { capacity (2014) was } 370 \\
\text { GW (REN21 2015) }\end{array}$ & $\begin{array}{l}\text { Strong opportunities for } \\
\text { innovation (e.g., taller, lighter } \\
\text { towers; longer, lighter blades; } \\
\text { light weighting of the nacelle } \\
\text { and rotor) }\end{array}$ \\
\hline $\begin{array}{l}\text { Automotive } \\
\text { LIB Cells }\end{array}$ & $\begin{array}{l}\text { Well-established } \\
\text { global } \\
\text { manufacturing } \\
\text { network }\end{array}$ & $\begin{array}{l}\text { HS codes available; } \\
\text { CEMAC study } \\
\text { completed }\end{array}$ & $\begin{array}{l}\text { Demand is expected to grow at } \\
\text { a } 31 \% \text { CAGR between } 2013 \\
\text { and } 2023 \text { (Alexander and } \\
\text { Gartner 2014). }\end{array}$ & $\begin{array}{l}\text { Estimated global annual } \\
\text { demand (2014) was } 9.6 \\
\text { GWh (Alexander and } \\
\text { Gartner 2014; BNEF } \\
\text { 2016a; BNEF 2016b; } \\
\text { BNEF 2016c; Inagaki } \\
\text { 2016; Pillot 2015) }\end{array}$ & $\begin{array}{l}\text { Medium to high (innovations in } \\
\text { cell chemistry, formats, and } \\
\text { manufacturing processes) }\end{array}$ \\
\hline $\begin{array}{l}\text { LED } \\
\text { Packages }\end{array}$ & $\begin{array}{l}\text { Well-established } \\
\text { global } \\
\text { manufacturing } \\
\text { network }\end{array}$ & $\begin{array}{l}\text { HS codes available } \\
\text { for LED dies and } \\
\text { packages; CEMAC } \\
\text { study launched FY16 }\end{array}$ & $\begin{array}{l}\text { Global revenue from LED } \\
\text { lighting systems is expected to } \\
\text { total U.S. } \$ 216 \text { billion between } \\
2015 \text { and } 2024 \text { (Navigant } \\
2015 \text { ) }\end{array}$ & $\begin{array}{l}\text { All LED applications have } \\
\text { the potential for energy } \\
\text { savings; LED lighting } \\
\text { could save } 395 \text { TWh by } \\
2030 \text { (Brodrick 2016) }\end{array}$ & $\begin{array}{l}\text { Medium (new LED housing } \\
\text { design for higher efficiency, } \\
\text { new LED chip designs to } \\
\text { eliminate phopshors, new LED } \\
\text { chip deposition processes) }\end{array}$ \\
\hline
\end{tabular}

\section{Clean Energy Technology Selection Criteria}

\author{
Global market size and/or \\ otential impact on \\ within manufacturing supply \\ Parbon intensity or \\ 2015, James 2015, \\ 2015) \\ capacity (2014) was 370 \\ innovation (e.g., taller, lighter \\ ; longer, lighter blades; \\ ight weighting of the nacelle \\ uggests a potential value of \\ Uillion USD, depending
} value chain data understood available or CEMAC cturing cost HS codes available Demand is expected to grow at and 2023 (Alexander and 2030 (Brodrick 2016)
BNEF 2016c; Inagaki

could save 395 TWh by chip deposition processes) 


\subsection{Application of Supply Chain Element Selection Criteria}

The first step in the benchmark development process is to align the clean energy technology manufacturing supply chain with the Benchmarks of Global Clean Energy Manufacturing (CEMAC 2017) framework. Based on past NREL/CEMAC analyses of c-Si solar PV modules, the specific supply-chain elements to be included in the report can be identified, as summarized in Table 5. 
Table 5. Benchmark Report Technology Supply Chain Element Criteria Summary

\begin{tabular}{|c|c|c|c|c|}
\hline $\begin{array}{l}\text { Clean Energy } \\
\text { Technology }\end{array}$ & Raw Materials & Processed Materials & Subcomponents & End Product \\
\hline $\begin{array}{l}\text { Intermediates } \\
\text { included in } \\
\text { benchmark } \\
\text { analysis }\end{array}$ & & Steel & $\begin{array}{l}\text { Generators (for market } \\
\text { analysis); generator sets (for } \\
\text { trade analysis) }\end{array}$ & $\begin{array}{c}\text { Wind turbine components: } \\
\text { blades, nacelle (generator as } \\
\text { proxy), tower }\end{array}$ \\
\hline $\begin{array}{l}\text { Summary of } \\
\text { CEMAC } \\
\text { analyst } \\
\text { evaluation }\end{array}$ & $\begin{array}{l}\text { Majority of raw materials is } \\
\text { not constrained (iron ore, } \\
\text { copper ore, carbon). Rare } \\
\text { earth metals for direct drive } \\
\text { magnetics are very } \\
\text { constrained (China produces } \\
90 \% \text { of global supply) but not } \\
\text { currently in widespread use. } \\
\text { (Sources: NREL, SNL, and } \\
\text { CEMAC analysis, DOE and } \\
\text { ARPA-E analysis) }\end{array}$ & $\begin{array}{l}\text { Steel is a major cost of wind } \\
\text { turbines. Limited large steel } \\
\text { casting facilities exist in the } \\
\text { United States. The majority of } \\
\text { cast parts for U.S. wind market } \\
\text { comes from Asia and not tracked } \\
\text { in HTS codes. Other key } \\
\text { materials (fiberglass, carbon fiber) } \\
\text { are not constrained. Rare earth } \\
\text { metals (neodyminum, } \\
\text { dysprosium) for direct drive } \\
\text { magnetics are very constrained } \\
\text { but not currently in widespread } \\
\text { use. (Sources: NREL/CEMAC } \\
\text { analysis, DOE and ARPA-E } \\
\text { analysis) }\end{array}$ & $\begin{array}{l}\text { Wind turbines have thousands } \\
\text { of subcomponents. } \\
\text { Imports/exports of generator } \\
\text { sets are tracked by HS code } \\
850231 \text {. In the United States, } \\
\text { generators are tracked by HTS } \\
\text { code } 8501640021 \text {. (Sources: } \\
\text { NREL/CEMAC analysis, } \\
\text { NREL/LBNL analysis) }\end{array}$ & $\begin{array}{l}\text { Wind turbines are a global } \\
\text { market with each main original } \\
\text { equipment manufacturer (OEM) } \\
\text { (e.g., GE, Siemens, Vestas, } \\
\text { Gamesa, Suzlon) having their } \\
\text { own supply chain. U.S. imports } \\
\text { of blades and hubs and towers } \\
\text { are tracked by HTS codes } \\
\text { (8412909081 and } 7308200020 \text {, } \\
\text { respectively). International six- } \\
\text { digit codes are not established } \\
\text { for these components. Wind } \\
\text { energy has the most-installed } \\
\text { capacity of any non-hydro } \\
\text { renewable energy source. The } \\
\text { global wind industry installed } \\
\text { more than } 51 \text { GW of capacity in } \\
2014, \text { bringing the global total to } \\
370 \text { GW. Although the wind } \\
\text { industry is well established and } \\
\text { growing, wind still constitutes } \\
\text { only } 3 \% \text { of global electricity. The } \\
\text { DOE (2015a) Wind Vision } \\
\text { estimates the U.S. wind } \\
\text { generation potential by } 2030 \text { as } \\
20 \% \text {, suggesting there still } \\
\text { remains strong opportunities for } \\
\text { growth and innovation in the } \\
\text { sector. }\end{array}$ \\
\hline
\end{tabular}




\begin{tabular}{|c|c|c|c|c|}
\hline $\begin{array}{l}\text { Clean Energy } \\
\text { Technology }\end{array}$ & Raw Materials & Processed Materials & Subcomponents & End Product \\
\hline $\begin{array}{l}\text { Intermediates } \\
\text { included in } \\
\text { benchmark } \\
\text { analysis }\end{array}$ & & Polysilicon & c-Si PV wafers and cells & c-Si PV modules \\
\hline $\begin{array}{l}\text { Summary of } \\
\text { CEMAC } \\
\text { analyst } \\
\text { evaluation }\end{array}$ & $\begin{array}{l}\text { No raw materials used in C-Si } \\
\text { PV manufacture supply chain } \\
\text { (e.g., silicon, aluminum, } \\
\text { copper) are constrained. } \\
\text { Silver is not constrained but } \\
\text { volatile in price and can } \\
\text { impact overall cell and } \\
\text { module pricing materially. } \\
\text { (Sources: NREL/CEMAC } \\
\text { analysis, academic literature, } \\
\text { market reports) }\end{array}$ & $\begin{array}{l}\text { Polysilicon is unique and enables } \\
\text { processed materials for c-Si PV } \\
\text { manufacturing; it is imported and } \\
\text { exported globally under HTS code } \\
280461 . \\
\text { Silver paste is also included as it } \\
\text { is currently the standard for } \\
\text { electrode screen printing. } \\
\text { (Sources: NREL/CEMAC } \\
\text { analysis, academic literature, } \\
\text { market reports) }\end{array}$ & $\begin{array}{l}\text { Wafers and cells are the key } \\
\text { enabling-intermediate products } \\
\text { used in the c-Si PV } \\
\text { manufacture supply chain; } \\
\text { included in HTS code } 854140 . \\
\text { (Sources: NREL/CEMAC } \\
\text { analysis, academic literature, } \\
\text { market reports) }\end{array}$ & $\begin{array}{l}\text { While the PV industry is well } \\
\text { established and maturing, PV } \\
\text { still constitutes only about } 1 \% \text { of } \\
\text { global electrical energy } \\
\text { production (BNEF 2015). The } \\
\text { DOE (2012) SunShot Vision } \\
\text { Study estimates that solar } \\
\text { energy could meet } 14 \% \text { of U.S. } \\
\text { electricity needs by } 2030 \text { and } \\
27 \% \text { by } 2050 \text {, suggesting there } \\
\text { still remains strong opportunities } \\
\text { for growth and innovation in the } \\
\text { sector. }\end{array}$ \\
\hline
\end{tabular}




\begin{tabular}{|c|c|c|c|c|}
\hline $\begin{array}{l}\text { Clean Energy } \\
\text { Technology }\end{array}$ & Raw Materials & Processed Materials & Subcomponents & End Product \\
\hline $\begin{array}{l}\text { Intermediates } \\
\text { included in } \\
\text { benchmark } \\
\text { analysis }\end{array}$ & & $\begin{array}{c}\text { Cathode materials, anode } \\
\text { materials, electrolyte materials }\end{array}$ & Separators & Li-ion battery cells \\
\hline $\begin{array}{l}\text { Summary of } \\
\text { CEMAC } \\
\text { analyst } \\
\text { evaluation }\end{array}$ & $\begin{array}{l}\text { Lithium is the core enabling } \\
\text { input material for Li-ion cells } \\
\text { and batteries. } \\
\text { Cobalt is also an important } \\
\text { enabling raw material in } \\
\text { nickel- manganese-cobalt } \\
\text { (NMC) )cathode production } \\
\text { and constitutes a material } \\
\text { portion of NMC power } \\
\text { production costs (and } \\
\text { therefore LIB cell costs). } \\
\text { Some } 50 \% \text { of cobalt ore } \\
\text { supply comes from sources } \\
\text { that do not employ socially } \\
\text { responsible mining practices. } \\
\text { (Sources: USGS, academic } \\
\text { literature, general press) }\end{array}$ & $\begin{array}{l}\text { Electrode and electrolyte } \\
\text { materials are critical in } \\
\text { determining the performance of } \\
\text { cells and battery packs. These } \\
\text { constitute the "chemistry" of any } \\
\text { battery system. Cell research is } \\
\text { focused on better performance } \\
\text { through improved chemistries. } \\
\text { (Sources: Academic literature, } \\
\text { market reports, conference } \\
\text { proceedings) }\end{array}$ & $\begin{array}{l}\text { Separators are the only } \\
\text { relatively unique and enabling } \\
\text { subcomponent recommended } \\
\text { for inclusion. Other } \\
\text { subcomponents tend to be } \\
\text { commodity materials or are not } \\
\text { especially technically } \\
\text { differentiable. (Sources: } \\
\text { Academic literature, market } \\
\text { reports, conference } \\
\text { proceedings) }\end{array}$ & $\begin{array}{l}\text { Li-ion battery manufacturing for } \\
\text { the automotive industry is in the } \\
\text { early stages of commercial } \\
\text { production, with electrified } \\
\text { vehicles (including pure electric, } \\
\text { plug-in hybrid, and hybrid drive } \\
\text { vehicles) constituting only } 1.6 \% \\
\text { of global light-duty vehicle } \\
\text { markets in } 2015 \text { (Navigant } \\
\text { Consulting } 2015 \text { ). The industry is } \\
\text { pursuing innovations in both core } \\
\text { cell chemistries and } \\
\text { manufacturing processes to } \\
\text { achieve cost reductions and } \\
\text { performance improvements, } \\
\text { which are key to electrified } \\
\text { vehicle market growth and } \\
\text { overall vehicle market } \\
\text { penetration. }\end{array}$ \\
\hline
\end{tabular}




\begin{tabular}{|c|c|c|c|c|}
\hline $\begin{array}{l}\text { Clean Energy } \\
\text { Technology }\end{array}$ & Raw Materials & Processed Materials & Subcomponents & End Product \\
\hline $\begin{array}{l}\text { Intermediates } \\
\text { included in } \\
\text { benchmark } \\
\text { analysis }\end{array}$ & & Sapphire substrate & LED chips & LED packages \\
\hline $\begin{array}{l}\text { CEMAC } \\
\text { analyst } \\
\text { evaluation }\end{array}$ & $\begin{array}{l}\text { Indium, gallium, yttrium, and } \\
\text { cerium (used in LED chips } \\
\text { and packages) are rare earth } \\
\text { materials. Additionally, } \\
\text { especially for yttrium, cerium, } \\
\text { and indium, the vast majority } \\
\text { of production takes place } \\
\text { within China, and these } \\
\text { materials are sometimes } \\
\text { subject to tariffs or export } \\
\text { quotas that can restrict supply } \\
\text { or increase prices } \\
\text { significantly. All these } \\
\text { materials are also critical to } \\
\text { quality. (Sources: USGS, } \\
\text { literature review, industry } \\
\text { interviews) }\end{array}$ & $\begin{array}{l}\text { YAG:Ce phosphor, the sapphire } \\
\text { substrate, and precursor } \\
\text { materials (TMG, TMI) are critical } \\
\text { to LED chip and package quality. } \\
\text { While LEDs can be produced with } \\
\text { alternative processed materials, } \\
\text { these have been unique and } \\
\text { enabling products that allow for } \\
\text { high performance and are used } \\
\text { by the vast majority of } \\
\text { manufacturers. These products } \\
\text { are imported and exported } \\
\text { globally and are important to } \\
\text { overall package costs. } \\
\text { Cold-roll steel is the main } \\
\text { component of } 2 x 2 \text { troffer housing. } \\
\text { It is significant in size and weight } \\
\text { of the overall product. A great } \\
\text { deal of steel manufacturing } \\
\text { happens in the United States. The } \\
\text { size of commercial lighting } \\
\text { creates an incentive to make the } \\
\text { housing for the luminaire locally } \\
\text { and thus reduces shipping costs. } \\
\text { (Sources: Literature review, data } \\
\text { base subscription, ITC, USGS) }\end{array}$ & $\begin{array}{l}\text { The LED chips and packages } \\
\text { are the components that } \\
\text { actually produce the light in the } \\
\text { LED luminaire. Their brightness } \\
\text { and quality is critical (although } \\
\text { not the sole determinant) of the } \\
\text { overall light quality and system } \\
\text { efficiency. While each individual } \\
\text { chip and package can be } \\
\text { relatively cheap, in commercial } \\
\text { lighting-where many of these } \\
\text { packages are used-they can } \\
\text { constitute a significant portion } \\
\text { of the overall luminaire cost. } \\
\text { The chip and package design } \\
\text { can also influence the overall } \\
\text { system design-for example, } \\
\text { the number of chips and } \\
\text { packages required or which } \\
\text { thermal management solutions } \\
\text { are used. These products are } \\
\text { also exported and imported } \\
\text { globally. (Sources: NREL } \\
\text { analysis, DOE SSL reports, } \\
\text { literature review, ITC) }\end{array}$ & $\begin{array}{l}\text { While LED packages (for a } \\
\text { variety of consumer applications) } \\
\text { have matured significantly in } \\
\text { recent years, costs remain high } \\
\text { and market penetration remains } \\
\text { low. LED lighting is poised for } \\
\text { growth. The DOE (2014) report } \\
\text { Energy Savings Forecast of } \\
\text { Solid-State Lighting in General } \\
\text { Illumination Applications projects } \\
\text { that LED lighting could achieve a } \\
\text { market share of } 84 \% \text { of lumen- } \\
\text { hour sales in the general } \\
\text { illumination market by } 2030 \text {, with } \\
\text { innovations focused on reducing } \\
\text { costs and improving efficacy of } \\
\text { LED package components and } \\
\text { housing design. }\end{array}$ \\
\hline
\end{tabular}




\subsection{Application of Economy Selection Criteria}

The economies included in the benchmark analysis are identified based on the criteria in Table 6 . For the four technologies assessed, the top countries are China, Japan, Malaysia, Taiwan, and South Korea, in addition to the United States.

Table 6. Economies Included in Benchmark Analysis

\begin{tabular}{|c|c|c|c|c|}
\hline Criteria & Wind Turbine Components & C-Si Solar PV Modules & LED Packages & Li-ion Battery Cells \\
\hline $\begin{array}{l}\text { Current economy } \\
\text { market size and } \\
\text { projected growth } \\
\text { relative to other } \\
\text { countries (technology- } \\
\text { specific) }\end{array}$ & $\begin{array}{l}\text { China, the United States, } \\
\text { Germany, Brazil, India = } \\
74 \% \text { global market (top } 3= \\
64.7 \% \text { ) }\end{array}$ & $\begin{array}{l}\text { China, Japan, the United } \\
\text { States, the United Kingdom, } \\
\text { Germany }=71 \% \text { of global } \\
\text { module demand }\end{array}$ & $\begin{array}{l}\text { The United States, Canada, } \\
\text { Japan, Europe, and China } \\
\text { make up over } 60 \% \text { of total LED } \\
\text { luminaire market }\end{array}$ & $\begin{array}{l}\text { The United States, Japan, } \\
\text { Germany, and China make } \\
\text { up } 90 \% \text { of global demand } \\
\text { for automotive cells }\end{array}$ \\
\hline $\begin{array}{l}\text { Current economy } \\
\text { manufacturing capacity } \\
\text { relative to other } \\
\text { countries (technology- } \\
\text { specific) }\end{array}$ & $\begin{array}{l}\text { Brazil, China, Germany, } \\
\text { India, US,= } 78 \% \text { of blade } \\
\text { capacity; } 84 \% \text { of nacelle } \\
\text { capacity, and } 67 \% \text { of tower } \\
\text { capacity }\end{array}$ & $\begin{array}{c}\text { China, Malaysia, Mexico, the } \\
\text { United States, South Korea = } \\
81 \% \text { of global capacity. } \\
\text { (Remaining countries: India, } \\
\text { Japan, Taiwan, Germany, } \\
\text { Singapore, Thailand, } \\
\text { Philippines, Canada, Czech } \\
\text { Republic) }\end{array}$ & $\begin{array}{l}\text { At the chip level: Taiwan, } \\
\text { Japan, Korea, and China made } \\
\text { up }>60 \% \text { of the global capacity } \\
\text { in } 2014 \text {; at the package level, } \\
\text { Japan, Korea, Europe, } \\
\text { Malaysia, the United States, } \\
\text { and China are top. }\end{array}$ & $\begin{array}{l}\text { China, Japan, the United } \\
\text { States, and South Korea } \\
\text { comprise } 94 \% \text { of } \\
\text { automotive cell } \\
\text { manufacturing capacity }\end{array}$ \\
\hline $\begin{array}{c}\text { Economy included in } \\
\text { value-added I-O } \\
\text { database }\end{array}$ & YES & YES & YES & YES \\
\hline $\begin{array}{l}\text { Economy included in } \\
\text { import-export database }\end{array}$ & $\begin{array}{l}\text { YES for generator sets only } \\
\text { (nacelles combined with } \\
\text { blades). }\end{array}$ & $\begin{array}{c}\text { YES, but level of detail varies } \\
\text { by economy. See Section } \\
7.2 .2 \text { for details. }\end{array}$ & $\begin{array}{c}\text { YES, but level of detail varies } \\
\text { by economy. See Section } 7.2 .2 \\
\text { for details. }\end{array}$ & $\begin{array}{l}\text { YES for rechargeable Li- } \\
\text { ion batteries for all } \\
\text { applications. }\end{array}$ \\
\hline
\end{tabular}




\subsection{Application of Value Added and Trade Benchmark Methodologies}

This section details the VA and international trade flow estimates for technologies included in Benchmarks of Global Clean Energy Manufacturing (CEMAC 2017). CEMAC analysts worked with the U.S. Department of Commerce and clean technology experts to employ consistent approaches for estimating trade flows from available data. Data confidence levels reported in Sections 6.4 and 6.5 use the color coding system described in Section 3.2

\subsubsection{Value Added Estimates}

As described in Section 5.2.4, VA estimates require that expenditures for each component be matched to one of 34 corresponding industries in the OECD I-O database (OECD 2015). Solar PV cells, for example, are within the computer, electronic, and optical equipment manufacturing sector because this industry contains semiconductor and photosensitive diode manufacturing. LED package and chip manufacturing are also photosensitive diodes, so they are also subsectors within this industry. Battery cells are also in the same industry as solar PV cells and LED packages and chips. Table 7 shows each of the components included in Benchmarks of Global Clean Energy Manufacturing (CEMAC 2017), along with its corresponding industry.

Table 7. OECD I-O Industry Categories Used for Supply Chain Elements Included in Benchmark Report

\begin{tabular}{|l|l|l|}
\hline Technology & Component & Industry \\
\hline \multirow{5}{*}{ Batteries } & Cells & Computers, electronic and optical equipment manufacturing \\
\cline { 2 - 3 } & Cathodes & $\begin{array}{l}\text { Electrical machinery and apparatus manufacturing, not elsewhere } \\
\text { classified }\end{array}$ \\
\cline { 2 - 3 } & Anodes & $\begin{array}{l}\text { Electrical machinery and apparatus manufacturing, not elsewhere } \\
\text { classified }\end{array}$ \\
\cline { 2 - 3 } & Separators & Rubber and plastics product manufacturing \\
\cline { 2 - 3 } & Electrolytes & Chemicals and chemical product manufacturing \\
\hline \multirow{5}{*}{ Solar PV } & Modules & Computers, electronic and optical equipment manufacturing \\
\cline { 2 - 3 } & Cells & Computers, electronic and optical equipment manufacturing \\
\cline { 2 - 3 } & Wafers & Computers, electronic and optical equipment manufacturing \\
\cline { 2 - 3 } & Polysilicon & Mining and quarrying \\
\hline \multirow{5}{*}{ Wind } & Packages & Computers, electronic and optical equipment manufacturing \\
\cline { 2 - 3 } & Chips & Computers, electronic and optical equipment manufacturing \\
\cline { 2 - 3 } & Sapphire & Other non-metallic mineral product manufacturing \\
\hline & Substrate & Machinery and equipment manufacturing, not elsewhere classified \\
\cline { 2 - 3 } & Nacelles & Manufacturing not elsewhere classified; recycling \\
\cline { 2 - 3 } & Tlades & Fabricated metal product manufacturing \\
\cline { 2 - 3 } & Steel & $\begin{array}{l}\text { Electrical machinery and apparatus manufacturing, not elsewhere } \\
\text { classified }\end{array}$ \\
\cline { 2 - 3 } & Generators &
\end{tabular}

To minimize double counting during VA analysis, total VA estimates zero out subcomponents for each sector in question in the technical coefficients within the SAM. ${ }^{7}$ For PV total VA, expenditures applied to the computer and electronic equipment industry would not include inputs for solar from cell and polysilicon manufacturing. In this example, computer and

\footnotetext{
${ }^{7}$ This is the social accounting matrix or the A matrix in Text Box A.
} 
electronic equipment industry (solar cells) or mining and quarrying (polysilicon) would be set to zero as not to include revenue from intermediate manufacturing steps. Table 8 shows the entire supply chain for each technology. The industries from Table 8 are set to zero to estimate the total VA. The VA for these subcomponents is still included in direct VA.

VA estimates for each subcomponent include the entire supply chain for that subcomponent to estimate the indirect VA for final products. Unlike total estimates, subcomponent VA is not controlled for double counting. Production of solar cells, for example, is included in the indirect impact for solar modules. In the previous example, direct VA from cells is included in indirect VA from modules.

Because VA estimates are calculated by using the SAM and revenue (calculated by multiplying production volume by the average selling price), the data quality of VA estimates is directly related to the data quality of production values. If production value is designated "yellow," then VA figures are also "yellow." This is also true for "green" and "gray" designations. (Color coding criteria are detailed in Section 3.2).

\subsubsection{Trade Flow Estimates}

Many clean energy commodities have specific HS codes, as shown in Table 8 . These are internationally consistent for polysilicon, rechargeable Li-ion batteries, wind generator sets, and photosensitive semiconductors (LEDs, solar PV cells, and modules).

Table 8. Six-Digit Harmonized System Codes for Select Clean Energy Technologies

\begin{tabular}{|l|l|l|}
\hline \multicolumn{1}{|c|}{ Technology } & Six-Digit HS Code & \multicolumn{1}{c|}{ Description } \\
\hline $\begin{array}{l}\text { LEDs and solar PV modules and } \\
\text { cells }\end{array}$ & 854140 & Includes all photosensitive semiconductors \\
\hline Polysilicon & 280461 & $\begin{array}{l}\text { Silicon containing by weight not less than } \\
99.99 \% \text { silicon }\end{array}$ \\
\hline Li-ion batteries & 850760 & All rechargeable Li-ion batteries \\
\hline Wind generator sets & 850231 & Wind generator sets \\
\hline
\end{tabular}

Breaking out individual subcomponents for photosensitive semiconductors presents a challenge because countries report its subcomponents differently. South Korea and Malaysia do not report subcomponents at all, and Japan does not report subcomponents for exports. China, Germany, India, and the United Kingdom separate solar PV components from LEDs but do not separate solar modules and cells. Japan separates LEDs and solar PV for imports only. The greatest level of disaggregation-separation of LEDs, solar modules, and solar cells-is in data from Brazil, Canada, Mexico, Taiwan, and the United States. Table 9 summarizes what data aggregation is reported by each country, and Table 10 shows country-specific trade codes used in this report. Country specific trade codes allow for greater trade data integrity. 
Table 9. Level of Detail in "Photosensitive Semiconductor" Trade Data for PV and LED Products

\begin{tabular}{|l|l|l|}
\hline \multicolumn{1}{|c|}{$\begin{array}{c}\text { Cells, modules, and LEDs } \\
\text { combined }\end{array}$} & \multicolumn{1}{c|}{$\begin{array}{c}\text { Disaggregate LEDs and solar } \\
\text { PV }\end{array}$} & $\begin{array}{c}\text { Disaggregate LEDs, cells, and } \\
\text { modules }\end{array}$ \\
\hline South Korea & China & Brazil \\
\hline Malaysia & Germany & Canada \\
\hline Japan (exports) & India & Mexico \\
\hline & Japan (imports) & Taiwan \\
\hline & United Kingdom & United States \\
\hline
\end{tabular}


Table 10. Country-Specific Codes for Four Clean Energy Technologies

\begin{tabular}{|c|c|c|c|c|c|c|c|}
\hline \multirow{2}{*}{$\begin{array}{l}\text { Technology } \\
\text { HS-6 }\end{array}$} & \multicolumn{4}{|c|}{ PV Modules } & \multirow{3}{*}{\begin{tabular}{|c|}
$\begin{array}{c}\text { Wind Turbine } \\
\text { Components }\end{array}$ \\
850231 \\
Generator Sets
\end{tabular}} & \multirow{3}{*}{$\begin{array}{l}\text { LED Packages } \\
854140 \text { (includes } \\
\text { solar PV modules } \\
\text { and cells) } \\
\text { LED Packages }\end{array}$} & \multirow{3}{*}{$\begin{array}{c}\begin{array}{c}\text { Li-ion Battery } \\
\text { Cells }\end{array} \\
\mathbf{8 5 0 7 6 0} \\
\end{array}$} \\
\hline & \multicolumn{3}{|c|}{854140 (includes LED packages) } & \multirow{2}{*}{\begin{tabular}{|c|}
280461 \\
Polysilicon
\end{tabular}} & & & \\
\hline & $\begin{array}{c}\text { PV Cells + } \\
\text { PV } \\
\text { Modules }\end{array}$ & PV Cells & PV Modules & & & & \\
\hline Brazil & & 85414016 & 85414032 & & & 85414011 & \\
\hline Canada & & 8541400023 & 8541400022 & & & & \\
\hline China & 85414020 & & & & & 85414010 & \\
\hline Germany & 85414090 & & & & & 85414010 & \\
\hline India & 85414011 & & & & & 85414020 & \\
\hline Japan & $854140020^{*}$ & & & & & $854140910^{*}$ & \\
\hline \multicolumn{8}{|l|}{ Malaysia } \\
\hline Mexico & & 85414003 & 85414002 & & & & \\
\hline \multicolumn{8}{|l|}{ South Korea } \\
\hline Taiwan & & 85414040006 & 85414040004 & & & $\begin{array}{l}85414029009 \\
85414021908\end{array}$ & \\
\hline United Kingdom & 35414090 & & & & & 85414010 & \\
\hline United States & & 8541406030 & 8541406020 & & & 8541402000 & \\
\hline * Imports Only & & & & & & 85414011 & \\
\hline
\end{tabular}


Estimation of trade activity requires many assumptions depending on data availability. Instead of solely using imports, as is the case with polysilicon, Li-ion batteries, and wind generator sets, exports of PV modules, cells, and LED packages are calculated from trade data from other countries rather than the one in question. Malaysia, for example, does not separate LEDs from solar PV; however, India does. Therefore, Indian exports to Malaysia are used instead of Malaysian imports from India.

Export data is not used to disaggregate LED and solar PV trade between South Korea and Malaysia because both countries do not separate LED, PV cell, and module trade values. In this case, average portions of LED and solar PV data over a three-year period-2012 to 2014- from China, Germany, and Taiwan was used to calculate the aggregated LED and solar PV trade between Malaysia and South Korea, as well as imports from Japan. Due to the multiple assumptions required to estimate trade data for South Korea, Malaysia, and Japan, this data is shown as gray (Table 11).

Table 11. Data Confidence Summary for LED, Solar PV Cell, and Module Trade Data

\begin{tabular}{|l|l|l|l|}
\hline & South Korea & Malaysia & Total Exports \\
\hline South Korea & & & \\
\hline Malaysia & & & \\
\hline Japan & & & \\
\hline Total Imports & & & \\
\hline
\end{tabular}

Disaggregating solar cells and modules requires further assumptions for trade data with other countries. Fewer countries distinguish between solar cell and module trade data, requiring a disaggregation process similar to the process used to separate LEDs from solar PV for Malaysia and South Korea. Solar cell and solar module trade as a percentage of total solar PV trade within reporting countries was applied to countries that did not report. Table 12 shows trade data quality for solar cells and modules. 
Table 12. Data Confidence Summary for Solar Cell and Module Trade Data

\begin{tabular}{|c|c|c|c|c|c|c|c|c|}
\hline & China & India & Germany & Japan & $\begin{array}{l}\text { South } \\
\text { Korea }\end{array}$ & Malaysia & $\begin{array}{l}\text { United } \\
\text { Kingdom }\end{array}$ & $\begin{array}{l}\text { Total } \\
\text { Exports }\end{array}$ \\
\hline China & & & & & & & & \\
\hline India & & & & & & & & \\
\hline German & & & & & & & & \\
\hline Japan & & & & & & & & \\
\hline $\begin{array}{l}\text { South } \\
\text { Korea }\end{array}$ & & & & & & & & \\
\hline Malaysia & & & & & & & & \\
\hline $\begin{array}{l}\text { United } \\
\text { Kingdom }\end{array}$ & & & & & & & & \\
\hline $\begin{array}{l}\text { Total } \\
\text { Imports }\end{array}$ & & & & & & & & \\
\hline
\end{tabular}

In addition to these assumptions, in several instances countries reported exports that were lower than imports reported by other countries. For example, Canada did not report any solar PV exports while other countries reported U.S. \$26 million in imports from Canada. In these instances, the sum of imports reported by countries in this report was used rather than exports reported by the country in question. As a result of this, these data are classified as "yellow" because they do not include potential exports to countries outside of this report (see Table 13). Underreporting of total imports is not as pervasive as underreporting of total exports, yet it still is a problem in the data (see Table 14).

Table 13. Data Confidence Summary for LED and Solar PV Export Data

\begin{tabular}{|l|l|l|}
\hline & Total Solar PV Exports & Total LED Exports \\
\hline Canada & & \\
\hline Germany & & \\
\hline Mexico & & \\
\hline Taiwan & & \\
\hline United States & & \\
\hline
\end{tabular}


Table 14. Data Confidence Summary for LED and Solar PV Import Data

\begin{tabular}{|l|l|l|l|}
\hline & China & Germany & Mexico \\
\hline Cell and Modules & & & \\
\hline LEDs & & & \\
\hline
\end{tabular}

Trade data in CEMAC (2017) also exclude Chinese reimports. China sometimes reports imports and exports of commodities to and from itself as well as Hong Kong, resulting in larger total export and import levels than actual trade value. Because this is primarily the movement of goods within China and is an artifact of reporting rather than trade outside of China and Hong Kong, we modify data to exclude this trade.

Given the different levels of reporting, we assume that LED and solar PV trade should sum to be equal at the six-digit level, which is not always the case. Typically, any differences are very small, less than U.S. $\$ 200,000$. All differences in trade data was less than U.S. $\$ 5$ million. NREL analysis of international production suggested that LED imports were likely too high, so differences between U.S. \$4 million and \$5 million, which was adjusted in the report. Table 15 shows countries in which LED trade was adjusted-there were only three such incidences (China to Mexico, Japan to China, and Taiwan to China). Because these adjustments were so small, data quality is yellow.

Table 15. Data Confidence Summary for LED Trade Data

\begin{tabular}{|l|l|l|}
\hline & China & Mexico \\
\hline China & & \\
\hline Japan & & \\
\hline Taiwan & & \\
\hline
\end{tabular}

Reporting of wind generator set and rechargeable li-ion battery trade required fewer assumptions than LED and solar PV trade. As with LEDs and solar PV, however, there were several instances of countries reporting lower total exports than the sum of what other countries reported importing from the country in question. In this case, the sum reported by other countries was used rather than the total export figure published by the country in question("yellow" values in Table 16). There were no instances of countries reporting total imports that were less than the sum of imports from countries in this report. 
Table 16. Data Confidence Summary for Wind and Battery Export Data

\begin{tabular}{|l|l|l|}
\hline & $\begin{array}{l}\text { Total Exports of Wind Generator } \\
\text { Sets }\end{array}$ & $\begin{array}{l}\text { Total Exports of Rechargeable } \\
\text { Li-lon Batteries }\end{array}$ \\
\hline Malaysia & & \\
\hline Taiwan & & \\
\hline United States & & \\
\hline
\end{tabular}

\subsection{Application of Market Benchmark Methodologies}

\subsubsection{Market Size (Demand) Estimates}

Many organizations track and report the market size and development of total global demand for clean energy technologies, as well as demand for their constituent intermediates. Market reports also typically present demand on a country-by-country basis. If such data were not readily available for certain technologies and supply chain links, various estimation methods were employed. Global demand for wind turbines was assumed to be equivalent to global system installed capacity in the benchmark year-annual installation capacity data were readily available from secondary sources. Intermediate product demand was also assumed to be equivalent to installed capacity because the intermediates analyzed in this report are typically delivered to project sites and subsequently assembled into wind turbines onsite.

\subsubsection{Wind Turbine Component Demand Estimates}

Global demand for wind turbines was assumed to be equivalent to global system installed capacity in the benchmark year. Annual installed capacity data were readily available from multiple sources with strong alignment. Estimated country-specific and global demand data for the analysis were derived from data reported by the Global Wind Energy Council (2016) for the benchmark year.

Although equating demand in the benchmark year with installed capacity in the same year is reasonably robust over the long term in a mature market, this assumption has some limitations in the current wind market. Namely, product demand may lag annual installed capacity due to requisite manufacturing and construction lead times necessary to construct and commission a plant in a given year. Moreover, depending on corporate strategy and individual supplier decisions, some equipment may be stockpiled based on expected changes in future demand and in order to efficiently manage variable demand with supply capacity that is relatively fixed over the short term. Both these potential limitations may result in some uncertainty in the estimated actual demand of wind turbines for the benchmark year, although it is not known whether these might result in higher or lower values for demand as it could easily vary between markets and individual suppliers.

Intermediate product demand was also assumed to be equivalent to installed capacity, as each individual turbine requires a full set of associated intermediates. In some cases, these intermediates may be assembled prior to transport to the project site (e.g., the generator and gearbox in to the nacelle), while in others, intermediates (e.g., the assembled nacelle) are 
transported to the project site as part of the plant construction process. Not unlike overall demand for wind turbines, this approach has some limitations depending on how quickly products are moving from the assembly line to the field and to commissioning or whether specific intermediaries are being stockpiled.

Table 17 provides a qualitative indication of relative confidence in total demand estimates. Premised on a strong annual correlation between installed capacity and turbine and component demand, our estimates of demand for nacelles, blades, towers, and generators on a megawatt basis are relatively confident. This confidence is merited given robust tracking of annual turbine installations among multiple sources, including the Global Wind Energy Council, whose data are applied here (i.e., we have strong confidence in the number of megawatts of each of these components that was installed in a given year). Estimates of steel are of lower confidence as they require secondary calculations of tonnage from installed capacity estimates, from average turbine parameters, and from average turbine steel intensity. Notably, estimates of specific units of nacelles, blades, towers, and generators would also be somewhat lower-thanestimated megawatts of demand. Expected lower confidence associated with specific unit counts also results from secondary calculations that are based on average turbine parameters that can vary quite broadly-for example, from 1-MW nameplate turbine generator capacity to more than $5 \mathrm{MW}$ for larger offshore wind turbines. Turbine-specific data are available, which could provide higher confidence in individual unit estimates, but there is much less uniformity and consistency among turbine-level data sets from an array of sources and countries.

Table 17. Data Confidence Summary for Wind Turbine and Intermediates Demand

\begin{tabular}{|l|l|l|l|l|}
\hline Nacelle & Blades & Tower & Generator & Steel \\
\hline & & & & \\
\hline
\end{tabular}

\subsubsection{C-Si PV Module Demand Estimates}

PV module demand data, as well as relatively detailed production data for constituent intermediate products, were available from two or more secondary sources. Global totals, as well as the country-specific data across sources, were in good alignment, and data across sources were generally averaged to arrive at the figures used in the demand analysis. This averaged data formed the basis of the market demand estimates presented in the report.

The PV-related processed materials and subcomponents analyzed in this report are consumed sequentially - that is, polysilicon is an input to wafer production, wafers are an input to cell production, and cells are an input to module production. Because of this, demand for each intermediate is assumed to be equal to the production volume of the subsequent product when all intermediate product volumes are expressed in similar units (i.e., demand for polysilicon [in $\mathrm{MW}$ ] is assumed equivalent to the production volume of wafers [in MW], and demand for wafers is equivalent to cell production volume, etc.). The global average selling price per megawatt for each intermediate is then multiplied by each demanded volume to arrive at demand for each product in terms of USD. Because production volumes and global pricing for each intermediate were available from one or more sources, this method allowed for the straightforward determination of demand for each intermediate product. 
Because polysilicon demand, capacity, and production are reported in terms of mass, an assumption regarding polysilicon consumption per megawatt of PV module produced was required in order to express volumes in a manner consistent with wafer, cell, and module volume reporting. Polysilicon consumption was assumed to be $5 \mathrm{~g} / \mathrm{W}$ of PV module output in 2014 (Osborne 2014).

Polysilicon manufacturing capacity can also produce polysilicon destined for non-PV applications in the semiconductor industry. To correct for this, it was assumed that $90 \%$ of polysilicon capacity and production was used in the PV industry (Mehta 2014) unless data sources specifically corrected for PV versus semiconductor use. The $90 \%$ assumption was applied equally to all capacity and production across all producer nations. Country-specific PV module demand was also corrected to reflect c-Si demand by assuming that $90 \%$ of total demand was fulfilled by c-Si modules (Mints 2015), with remaining demand served by thin-film technologies. This split was also applied to all country demand figures equally.

As shown in Table 18, the data confidence for polysilicon demand is noted as yellow because of the multiple assumptions applied in deriving the demand estimate, including: converting polysilicon mass to units of module power ( $5 \mathrm{~g}$ or polysilicon per watt of module power); applying a global average polysilicon price assumption of $\$ 0.092 / \mathrm{W}$; and relying on a single source for wafer production data, which underpins the polysilicon demand estimate.

The data confidence for wafer demand is also noted as yellow because of uncertainties in the country-specific cell production values (which underpins the volumetric wafer demand estimate) for a few small producer nations because there are inconsistencies among sources and assuming application of a global selling price of $\$ 0.235 / \mathrm{W}$ wafer.

Table 18. Data Confidence Summary for c-Si PV Module and Intermediates Demand

\begin{tabular}{|l|l|l|l|}
\hline PV Module & PV Cell & PV Wafer & Polysilicon \\
\hline & & & \\
\hline
\end{tabular}

\subsubsection{LED Package Demand Estimates}

The demand for LED packages is not available. For the purposes of the report and for calculation purposes only, it was assumed to be equal to the production. Trade flows show where some of the packages end up; however, given that many of the countries that produced LED packages consumed them for upstream products, trade flows were not a feasible method of determining demand. For the report, demand for packages should be ignored as merely a place holder and pseudo number for calculation.

The LED-related subcomponents analyzed in this report are consumed sequentially-that is, sapphire substrates are an input to LED chip production, and LED chip production is an input to LED package production. Because of this, demand for each intermediate is assumed to be equal to the production volume of the subsequent product when all intermediate product volumes are expressed in similar units (i.e., demand for sapphire substrate [in packages] is assumed to be equivalent to the production volume of LED chips [in packages], and the demand for package 
is assumed to be equal to the production of packages). The global average selling price for each stage of production was obtained from market reports. The ASP for packages was verified against publicly available information, which allowed confirmation that the data in the market report was accurate.

The data confidence for LED package demand is orange due to it just being assumed to be the production in the country it was produced in (see Table 19). This is known to not be true; however, it was a consistent assumption. The data confidence for LED chips demand is noted as yellow due to the multiple assumptions applied in deriving the demand estimate, including converting from package demand to chip demand. An assumption of chips per package was needed. Further, the production for packages was based on a single source. The data confidence for sapphire substrate demand is also noted as green because it was explicitly known which countries where producing chips and how many substrates would be needed to meet that demand.

Table 19. Data Confidence Summary for LED Package Demand

\begin{tabular}{|l|l|l|}
\hline LED Package & LED Chip & Sapphire Substrate \\
\hline & & \\
\hline
\end{tabular}

\subsubsection{Lithium-ion Battery Cell Demand Estimates}

Automotive Li-ion cell demand estimates were derived from electrified light-duty vehicle pack manufacturing volumes (pack size as well as pack volume) and country-specific locations, as pack manufacturing drives cell demand. These estimates were produced in terms of total cell storage capacity demanded, expressed in gigawatt-hours. Cell demand volumes were then multiplied by an assumed average cell selling price to derive demand estimates in terms of value (USD).

Reported costs, prices, demand, capacity, and production for Li-ion cells and their major constituent intermediate products are reported in slightly different normalized terms: cell metrics are normalized to storage capacity (per GWh); cathode, anode, and electrolytes are normalized to mass (per metric tonne); and separators are normalized to area (per square meter). Various engineering assumptions were thus required to convert intermediate demand, capacity, and production figures into units of capacity. The assumptions used include the following:

- Cell energy density: $0.072 \mathrm{kWh}$ per cell

- Cathode active materials: 1,890 metric tonnes per GWh of cell storage capacity (includes a $2 \%$ scrap rate assumption)

- Anode active materials: 1,109 metric tonnes per GWh of cell storage capacity (includes a $2 \%$ scrap rate assumption)

- Separator materials: 14 million $\mathrm{m}^{2} / \mathrm{GWh}$ of cell storage capacity (includes a $0.5 \%$ scrap rate assumption) 
- Electrolyte materials: 1,250 metric tonnes per GWh of cell storage capacity.

The data confidence for all intermediates are noted as moderate because of multiple assumptions applied to each estimate (Table 20).

Table 20. Data Confidence Summary for Li-ion Battery Cell Demand

\begin{tabular}{|c|c|c|c|c|}
\hline Li-ion Battery Cell & Cathode & Anode & Separator & Electrolyte \\
\hline
\end{tabular}

\subsubsection{Manufacturing Capacity and Production Estimates}

Manufacturing capacity and production data for end products and intermediates were estimated based on data from secondary sources specific to each clean energy technology.

\subsubsection{Wind Turbine Components Manufacturing Capacity and Production Estimates}

Manufacturing capacity data for wind turbines, nacelles, blades, towers, and generators were derived from original data supplied by MAKE Consulting, a global wind industry consultancy headquartered in Denmark and with offices in North America and Asia (MAKE Consulting 2016). These data are denoted yellow on our qualitative confidence indicator scheme (Table 21) as comparable data from other independent sources were not consistent in all cases with data reported by MAKE. In addition, it is recognized that there is far less concerted effort to normalize standards and definitions of wind turbine supplier manufacturing capacity than in the annual installed capacity data we use as a metric of demand. Nevertheless, these data are believed to provide among the best available estimates of production capacity.

Manufacturing capacity for steel supply of wind turbines is assumed to be equal to demand. This assumption is grounded in the fact that the wind turbine industry is a significant consumer of steel, but at the same time, it is not an investment driver in the siting and locating of steel production facilities. Data confidence for this material is given a relatively lower gray marking in our confidence scheme, as it is unlikely that any single country's wind turbine steel production capacity is actually equivalent to its demand. However-partially justifying our assumption - for some countries such as China, the world's largest wind turbine market, it is not implausible that all wind turbine steel demand is sourced from manufacturing capacity that is located domestically. Ultimately, more original data are needed if one is to better understand the location of steel manufacturing facilities supporting the global wind industry.

Production estimate data for wind turbines, nacelles, blades, towers, and generators were calculated by allocating manufacturing capacity to global demand on a proportional basis for each specific country. In other words, we assumed that a given country captured a portion of global demand commensurate with its existing manufacturing capacity for a specific component. As this approach resulted in some apparent anomalies, we subsequently applied subjective quantitative adjustments to individual country component-specific production levels based on expert knowledge of production for the benchmark year. Similarly, manufacturing capacity for steel estimates of steel production was simply assumed to be equivalent to demand. 
At the level of production, nacelles, blades, towers, and generators are denoted with a yellow designation in our qualitative confidence scheme (Table 21). The yellow designation is based on the fact that these data are calculated, with some subjective adjustments incorporated post calculations. However, these components did not receive the lowest gray data quality designation because they are fundamentally grounded in a methodological approach to estimation. Improving on this approach is likely to require the development of new original raw data sets tracking actual supplier-specific production levels. Steel production is denoted with the lower confidence gray designation, for reasons similar to the gray designation on manufacturing capacity.

Table 21. Data Confidence Summary for Wind Turbine Component Manufacturing Capacity and Production

\begin{tabular}{|l|l|l|l|l|l|}
\hline \multicolumn{1}{|c|}{ Benchmark } & Nacelle & Blades & Tower & Generator & Steel \\
\hline Manufacturing Capacity & & & & \\
\hline Production & & & & \\
\hline
\end{tabular}

\subsubsection{C-Si PV Module Manufacturing Capacity and Production Estimates}

Manufacturing capacity and production data for PV modules and their intermediate products were available from two or more secondary sources, with the exception of wafer production data, which was available from only a single source. Global totals, as well as the country-specific data across sources, were in reasonable alignment with a few minor exceptions, and data across sources were generally averaged to arrive at the figures reported for capacity and production analysis. As noted previously, production data formed the basis of the market demand estimates presented in the report. Source data for manufacturing capacity and production was reported in terms of volume per year, with polysilicon production being reported in USD per kilogram and all other intermediate products, as well as the end product, reported in megawatts per year. These data were multiplied by global average selling prices to arrive at the estimates of annual manufacturing capacity and production used in this report.

The data confidence for polysilicon capacity and production are noted as yellow because of the multiple assumptions applied in deriving the estimates, including: converting polysilicon mass to units of module power ( $5 \mathrm{~g}$ or polysilicon per watt of module power); assuming a blanket $90 \%$ of reported country-specific capacity and production were used in the PV industry (where sources did not specify intended markets); and applying a global average polysilicon price assumption of \$0.092/W (see Table 22).

The data confidence for wafer and cell production is also noted as yellow because of uncertainties in the country-specific cell production values (which underpins the volumetric wafer demand estimate) for a few small producer nations because of inconsistencies among sources; using only a single source for wafer production values; and applying a global selling price assumptions of $\$ 0.24 / \mathrm{W}$ for wafers and $\$ 0.037 / \mathrm{W}$ for cells. 
Table 22. Data Confidence Summary for C-Si PV Module Manufacturing Capacity and Production

\begin{tabular}{|l|l|l|l|l|}
\hline Benchmark & PV Module & PV Cell & PV Wafer & Polysilicon \\
\hline Manufacturing Capacity & & & & \\
\hline Production & & & & \\
\hline
\end{tabular}

\subsubsection{LED Package Manufacturing Capacity and Production Estimates}

Manufacturing production for LED packages was from a single source. The production data matches up with data in publicly available sources. Manufacturing capacity for LED packages is orange because it was assumed to be equal to production. Manufacturing of packages does not require any specialized equipment. There are no limiting factors preventing production ramping. It is assumed that capacity is just equal to the needs of production.

The manufacturing capacity of LED chips and sapphire substrates was from single sources. Manufacturing chips and substrates require very large expensive pieces of whose production is tracked. Therefore, the manufacturing capacity is green because it is well known where the necessary equipment ultimately ends up (see Table 23).

The manufacturing production of LED chips is green because these data were compiled from a market report.

The manufacturing production of sapphire substrates is yellow because of the assumption that a country's production was in line with its capacity. The capacity for substrate manufacturing was well known. The demand for substrates was well known. However, it was also vertically integrated into many companies. Therefore, one cannot know if the substrate was purchased or done internally. To produce the value for the report, each country was assumed to use its available capacity in the same amount as any other location.

Table 23. Data Confidence Summary for LED Package Manufacturing Capacity and Production

\begin{tabular}{|l|l|l|l|}
\hline Benchmark & LED Package & LED Chip & Sapphire Substrate \\
\hline $\begin{array}{l}\text { Manufacturing } \\
\text { Capacity }\end{array}$ & & & \\
\hline Production & & & \\
\hline
\end{tabular}

\subsubsection{Lithium-ion Battery Cell Manufacturing Capacity and Production Estimates}

Manufacturing capacity for cells and their constituent intermediates can also produce products destined for non-automotive applications. To correct for this, it was assumed that $18 \%$ of Li-ion cell and related intermediate production went to support automotive light-duty vehicle applications. The $18 \%$ assumption was applied equally to all capacity and production across all producer nations. This value was derived by averaging the automotive-related Li-ion cell market share from multiple sources (Inagaki 2016; Pillot 2015; Jaffe 2014). 
The data confidence for all intermediates is noted as moderate due to multiple assumptions applied to each estimate (Table 24). Assumptions applied to each estimate of intermediate capacity and production include: converting each intermediate volume metric into units of cell storage capacity; applying estimated global average selling prices to each intermediate product; adjusting some country-specific estimates of production in proportion to that country's share of capacity; and applying an assumption of intermediate product capacity and production supporting automotive light-duty vehicle applications derived from global data to the countryspecific level.

Table 24. Data Confidence Summary for Li-ion Battery Cell Manufacturing Capacity

\begin{tabular}{|l|l|l|l|l|l|}
\hline Benchmark & $\begin{array}{l}\text { Li-ion Battery } \\
\text { Cell }\end{array}$ & Cathode & Anode & Separator & Electrolyte \\
\hline Manufacturing Capacity & & & & & \\
\hline Production & & & & & \\
\hline
\end{tabular}




\section{References}

Alexander, David, and John Gartner. 2013. Electric Vehicle Batteries - Lithium Ion Batteries for Hybrid, Plug-in Hybrid, and Battery Electric Light Duty Vehicles: Market Analysis and Forecasts. Boulder, CO: Navigant Research.

Anand, Mohit. 2015. Global PV Manufacturing Attractiveness Index 2015 (PVMAX). GTM Research. Accessed January 9, 2017.

https://www.greentechmedia.com/research/report/global-pv-manufacturing-attractivenessindex-2015.

Anderman, Menahem. 2013. Assessing the Future of Hybrid and Electric Vehicles: The 2014 xEV Industry Insider Report. Needham, MA: Advanced Automotive Batteries.

BEA (Bureau of Economic Analysis). 2017. "Industry Economic Accounts." U.S. Department of Commerce. Accessed January 13, 2017. https://www.bea.gov/industry/.

BNEF (Bloomberg New Energy Finance). 2015. "Global PV Demand, 2006-2014 and Forecast." Bloomberg New Energy Finance Desktop Portal. Accessed August 17, 2016.

- - . 2016a. “Data: Manufacturing Plants." Bloomberg New Energy Finance Desktop Portal. Accessed August 21.

- - . 2016b. "Electric and Hybrid Vehicle Sales Dashboard." Bloomberg New Energy Finance Desktop Portal. Accessed May 26.

- - - 2016c. "Electric Vehicle Data." Bloomberg New Energy Finance Desktop Portal.

Accessed May 26.

Brodrick, James, ed. 2016. Solid-State Lighting R\&D Plan. DOE/EE-1418. Washington, DC: U.S. Department of Energy. Accessed January 9, 2017.

http://energy.gov/sites/prod/files/2016/06/f32/ssl rd-plan \%20jun2016 2.pdf.

CEMAC. 2017. Benchmarks of Global Clean Energy Manufacturing-2014. Golden, CO: National Renewable Energy Laboratory.

DOE (U.S. Department of Energy). 2015a. WindVision: A New Era for Wind Power in the United States. DOE/GO-102015-4557. Washington, DC: DOE. Accessed January 9, 2017.

https://www.energy.gov/sites/prod/files/WindVision Report final.pdf.

- - . 2015b. 2016-2020 STRATEGIC PLAN and Implementing Framework. DOE/EE-1061.

Washington, DC: Office of Energy Efficiency and Renewable Energy. Accessed January 9, 2017. http://energy.gov/sites/prod/files/2015/12/f27/EERE Strategic Plan 12.16.15.pdf.

- - . 2014. Energy Savings Forecast of Solid-State Lighting in General Illumination Applications. Washington, DC: DOE. Accessed January 9, 2017. https://www.energy.gov/sites/prod/files/2015/05/f22/energysavingsforecast14.pdf.

- - - 2012. SunShot Vision Study. Washington, DC: DOE. Accessed January 9, 2017. https://energy.gov/sites/prod/files/2014/01/f7/47927.pdf. 
Eurostat. 2017. “European Commission.” Accessed January 13, 2017.

http://ec.europa.eu/eurostat.

GWEC (Global Wind Energy Council). 2016. Accessed December 22, 2016.

http://www.gwec.net/.

Inagaki, Sachiya. 2016. “Battery Japan 2016 - LiB Materials Market Trends." Paper presented at the Battery Japan, Tokyo, Japan, March 2.

IEA (International Energy Agency). 2015. World Energy Outlook 2015. Accessed January 11, 2017. http://www.worldenergyoutlook.org/weo2015/.

ITA (International Trade Administration). 2015. "Top Markets: A Market Assessment Tool for U.S. Exporters." Washington, DC: U.S. Department of Commerce. Accessed January 9, 2017. http://www.trade.gov/topmarkets/.

ITC (International Trade Centre). 2017a. "Trade Map.” Accessed January 13, 2017. http://trademap.org/Index.aspx.

- - .2017b. "Market Analysis Tools Portal." Accessed January 13, 2017.

http://legacy.intracen.org/marketanalysis/.

Jaffe, Sam. 2014. "Materials for Advanced Batteries - Cathodes, Anodes, Electrolytes, Separators, and Other Materials for Advanced Batteries: Supply Chain Logistics and Market Sizing and Forecasts." Boulder, CO: Navigant Research.

James, Ted and Alan Goodrich. 2013. Supply Chain and Blade Manufacturing Considerations in the Global Wind Industry. NREL/PR-6A20-60063. Golden, CO: National Renewable Energy Laboratory. http://www.nrel.gov/docs/fy14osti/60063.Pdf.

Labastida, Roberto Rodriguez, and Dexter Gauntlett. 2015. Distributed Solar PV: Market Drivers and Barriers, Technology Trends, Competitive Landscape, and Global Market Forecasts. Boulder, CO: Navigant Research.

Make Consulting. 2016. Accessed December 22, 2016. http://www.consultmake.com/.

Mehta, Shyam. 2014. "The Shifting Relationship Between Solar and Silicon in Charts." Greentech Media, Feb. 3. Accessed January 9, 2017. http://www.greentechmedia.com/articles/read/Solar-and-Silicons-Shifting-Relationship-inCharts.

Miller, Ronald E., and Peter D. Blair. 2009. Input-Output Analysis Foundations and Extensions 2nd Edition. Cambridge: Cambridge University Press. ISBN: 9780521517133

Mints, Paula. 2015. "Photovoltaic Manufacturer Capacity, Shipments, Price \& Revenues." Market Research Report SPV-Supply3. San Francisco, CA: SPV Market Research.

Navigant Research. 2015. "LED Lighting: Global Outlook Commercial, Residential, Industrial, Outdoor, and Automotive Markets: Global Market Analysis and Forecasts." Accessed January 9, 2017. https://www.navigantresearch.com/research/led-lighting-global-outlook. 
OECD. 2016. "STAN STructural ANalysis Database." Accessed January 9, 2017.

http://www.oecd.org/sti/ind/stanstructuralanalysisdatabase.htm.

Osborne, Mark. 2014. "Polysilicon Demand Outpacing Silicon Per-Watt Reduction Strategies."

PV-Tech, Feb. 10. Accessed January 9, 2017. http://www.pv-

tech.org/news/polysilicon demand outpacing silicon per watt reduction strategies.

Pillot, Christophe. 2015. "Battery Market Development for Consumer Electronics, Automotive, and Industrial: Materials Requirements and Trends." Paper presented at the 5th Israeli Power Sources Conference 2015, Herzelia, Israel, May 21.

REN21. 2015. Renewables 2015: Global Status Report. ISBN 978-3-9815934-7-1. Paris: REN21 Secretariat. Accessed January 11, 2017. http://www.ren21.net/wpcontent/uploads/2015/07/GSR2015 KeyFindings lowres.pdf.

USITC (U.S. International Trade Commission). 2017a. "Interactive Trade and Tariff Database." Accessed January 13, 2017. https://dataweb.usitc.gov. 


\section{Glossary}

Balance of trade. Balance of trade is the difference between a country's imports and its exports for a given time period.

Clean energy technologies. Clean energy technologies are those that produce energy with fewer environmental impacts than conventional technologies or that enable existing technologies to operate more efficiently, consuming fewer natural resources to deliver energy services. Clean energy technologies may include renewable energy, clean non-renewable energy, and energy efficiency technologies for electricity generation, fuel production, and sustainable transportation.

Clean energy technology end product. The end product is the finished product of the manufacturing process, assembled from subcomponents, and ready for sale to customers as a completed item. Clean energy examples include solar PV modules and LED luminaires. In this link of the value chain, value added comes from assembling subcomponents into a marketable product that customers value.

Clean energy technology manufacturing. This is manufacturing of clean energy products (renewable energy, sustainable transportation, and energy efficiency technologies) and boosting U.S. manufacturing across the board by increasing energy productivity and low-cost domestic fuels and feedstocks (DOE 2015b).

Direct value added. Direct value added is value added from the output of the sector in question. For example, if solar module manufacturing pulled in U.S. \$100 million in revenue in a specific country and $70 \%$ of that went to intermediate inputs, then direct value added would be the remaining $30 \%$.

Final demand (FD). Final demand is demand for what is produced by an industry that is not an input for some other product. This demand can come from households, investors, governments, and the rest of the world through net exports. FD is also a measure of GDP.

Gross output. Gross output is the sum of value added and all payments for intermediate inputs. This is a measure of overall economic activity. Gross output is final demand plus intermediate demand or intermediate demand plus value added.

Indirect value added. Indirect value added is value added that is supported by the domestic intermediate expenditures made by the sector in question. This is a comprehensive figure that captures all value chain activity necessary to support the output of the sector in question within the country in question. Indirect value added from solar module manufacturing in China, for example, would not include polysilicon that is imported from the United States-this is estimated separately.

Intermediate inputs. Intermediate inputs are payments by a business or industry to other businesses and industries for goods or services used in production.

Manufacturing capacity. The manufacturing capacity is the amount of product that can be produced in a given time period by existing physical plants and other necessary infrastructure 
(e.g., megawatts of PV modules per year). Production is the actual amount of a product produced, also normalized to a given time period. Manufacturing capacity and production together reflect supply. Capacity and production, in combination with market size and growth, are the basic metrics used in assessing the supply, demand, and trade flow dynamics occurring within an industry.

Manufacturing supply chain. A supply chain is a complex and dynamic supply and demand network consisting of an integrated system of organizations, people, activities, information, and resources involved in moving a product or service from supplier to customer. Supply-chain activities involve the procurement, transformation, and logistics of natural resources, raw materials, and components into a finished product that is delivered to the end customer.

Manufacturing value chain. A value chain describes the value created in each step of the supply chain though the key activities that companies do to bring a product from its conception to its end use. Value-chain activities can produce goods or services, include a single company or span multiple companies, and occur within a single geographical location or spread across countries. While the supply chain tracks the flows of raw materials and intermediate products to customers (upstream to downstream), the value chain tracks the demand and cash flows from customers to companies (downstream to upstream).

Market size. Market size is an estimate of the demand for a specific product or service and is typically expressed in units of product volume (e.g., megawatts of PV modules) and in terms of monetary value (e.g., USD). The latter expression of market size accounts for both demand volumes and selling prices. Market size serves as a core metric of demand development and growth over time and is a key measure of the relative importance of an industry within countries and across the globe.

Processed materials. A processed material is a material that has been transformed or refined from a basic raw material as an intermediate step in the manufacturing process. Processed materials include steel, glass, and cement. In this link of the value chain, value added comes from processing raw materials into precursors that can be more easily transported, stored, and used for downstream subcomponent fabrication.

Raw materials. A raw material, or unprocessed material, is a basic material, mined, extracted, or harvested from the earth. Examples include raw biomass and iron ore. In this link of the value chain, value added comes from extracting, harvesting, and preparing raw materials for international marketing in substantial volumes.

Retained value added. A measure of an industry's contribution to GDP per unit of production. Value added retained is calculated by dividing manufacturing value added by production revenue. High wages and larger economies tend to retain higher levels of value added, as more inputs can be sourced domestically and workers are paid higher wages.

Social accounting matrix (SAM). SAM is a matrix that contains economy-wide data for value added, final demand, intermediate inputs, and gross output.

Subcomponents. A subcomponent is a unique constituent part or element that contributes to a 
finished product. Clean energy technology examples include blades for wind turbines and c-Si wafers for solar PV modules. The component to the manufacturer could be considered the finished product of their supplier. In this link of the value chain, value added comes from fabricating processed materials into subcomponents that can then be assembled (with other subcomponents) into end products.

Technical coefficients. Technical coefficients are intermediate inputs as a portion of output for each industry. When all technical coefficients are combined in a matrix, it is referred to as the direct requirements matrix.

Trade flows. Trade flows are the buying and selling of goods and services between countries. Trade flows measure the balance of trade (i.e., the amount of goods that one country sells to other countries [exports] minus the amount of goods that a country buys from other countries [imports]).

Value added (VA). The VA of an industry, also referred to as gross domestic product (GDP)- by industry, is the contribution from a private industry or government sector to overall GDP. VA consists of labor payments, gross operating surplus, and taxes and can be a measure of GDP. Labor payments are all payments to workers, including benefits. Gross operating surplus is a property-type income that includes payments for capital (including depreciation) and payments to investors. Profits are included in a gross operating surplus. Taxes are net payments to or from the government. If subsidies paid to an industry from the government are greater than taxes paid by that industry to the government, then taxes will be negative.

Wind generator sets. CEMAC defines wind generator sets as assembled nacelles shipped with blades. 